\title{
Metallic Organic Framework-Derived Fe, N, S co-doped Carbon as a Robust Catalyst for the Oxygen Reduction Reaction in Microbial Fuel Cells
}

\author{
Xiao Luo *, Wuli Han, Han Ren and Qingzuo Zhuang \\ College of Chemistry \& Environmental Engineering, Yangtze University, Jingzhou 434000, China; \\ hanwulilizi@163.com (W.H.); Rhamburger@163.com (H.R.); 18871536330@163.com (Q.Z.) \\ * Correspondence: 500460@yangtzeu.edu.cn; Tel.: +86-136-8905-9672
}

Received: 22 August 2019; Accepted: 30 September 2019; Published: 11 October 2019

check for updates

\begin{abstract}
Oxygen reduction reaction (ORR) provides a vital role for microbial fuel cells (MFCs) due to its slow reaction kinetics compared with the anodic oxidation reaction. How to develop new materials with low cost, high efficacy, and eco-friendliness which could replace platinum-based electrocatalysis is a challenge that we have to resolve. In this work, we accomplished this successfully by means of a facile strategy to synthesize a metallic organic framework-derived Fe, N, S co-doped carbon with FeS as the main phase. The Fe/S@N/C-0.5 catalyst demonstrated outstandingly enhanced ORR activity in neutral PBS and alkaline media, compared to that of commercial 20\% Pt-C catalyst. Here, we started-up and operated two parallel single-chamber microbial fuel cells of an air cathode, and those cathode catalysts were Fe/S@N/C-0.5 and commercial Pt-C (20\% Pt), respectively. Scanning electron microscopy (SEM) elaborated that the Fe/S@N/C-0.5 composite did not change the polyhedron morphology of ZIF-8. According to X-ray diffractometry(XRD) curves, the main crystal phase of the resulted Fe/S@N/C-0.5 was FeS. The chemical environment of N, S, and Fe which are anticipated to be the high-efficiency active sites of ORR for MFCs were investigated by X-ray photoelectron spectroscopic(XPS). Nitrogen adsorption/desorption techniques were used to calculate the pore diameter distribution. In brief, the obtained Fe/S@N/C-0.5 material exhibited a pronounced reduction potential at $0.861 \mathrm{~V}$ (versus Reversible Hydrogen Electrode(RHE)) in $0.1 \mathrm{M} \mathrm{KOH}$ solution and $-0.03 \mathrm{~V}$ (vs. SCE) in the PBS solution, which both outperform the benchmark platinum-based catalysts. Fe/S@N/C-0.5-MFC had a higher Open Circuit Voltage $(\mathrm{OCV})(0.71 \mathrm{~V})$, stronger maximum power density $\left(1196 \mathrm{~mW} / \mathrm{m}^{2}\right)$, and larger output voltage $(0.47 \mathrm{~V})$ than the $\mathrm{Pt} / \mathrm{C}-\mathrm{MFC}$ under the same conditions.
\end{abstract}

Keywords: electro-catalysis; oxygen reduction reaction; microbial fuel cells; Fe, N, S co-doped

\section{Introduction}

Recently, due to the increasing concern about the shortage of energy and the pollution of the environment, it has become inevitable to develop environmentally friendly and renewable energy plants such as $\mathrm{Zn}$-Air batteries, fuel cell and lithium-air batteries, etc. [1-5]. Electrochemical reactions are an important process in which oxygen reduction reaction (ORR) plays a vital role. Because ORR is a bottleneck having slow reaction kinetics, and thus, efficiency of ORR depends heavily on the catalyst used [6-8]. It is also one of the obstacles in microbial fuel cells (MFCs) whose electron acceptor is oxygen, and the research of cathode catalysts has also become a hot spot [9]. In an MFC, electrochemically active bacteria attached to the anode electrode provide electrons while oxidizing organic matter, and the resulting electrons flow from the anode through a wire to the cathode producing an electric current. Electron acceptors are reduced on a cathode during the reaction. MFCs have great development potential compared with other fuel cells because they can generate electricity by 
microbial reactions while removing organic pollutants in wastewater [10]. Organic matters such as glucose, peptone, and sodium acetate are consumed as a nutritious source for the microbial community at the anode, and oxygen reduction reaction (ORR) occurs at the cathode. So far, the state-of-the art platinum or alloyed platinum noble metal materials have shown excellent performance in ORR, but the weakness is obvious. Their intolerable cost, low reserves, inferior durability, and also the issue of methanol crossover have severely handicapped the application of the new devices [11]. Therefore, developing new, efficient, cheap, and stable non-noble metal composite catalysts is important [12]. Some transition metals (Fe, Co, Mn), which have to a certain extent exhibited catalytic activity for ORR, have attracted many researchers' attention. Especially, a variety of transition metal compounds, such as carbides/nitrides, oxides, and chalcogenides, showing good stability in ORR have been studied already [13-15]. Unfortunately, the performance of the transition metals-based catalysts is not satisfactory in acidic media. In order to solve this problem, many solutions have been proposed. Transition-metal-coordinating the doping of heteroatom (S, P, N) carbon-based materials demonstrated good activity and stability in ORR, especially in acidic medium $[16,17]$. Zhong et al. reported a facile approach for the in situ anchoring of $\mathrm{CO}_{9} \mathrm{~S}_{8}$ nanoparticles on nitrogen and sulfur co-doped porous carbon as an efficient catalyst for ORR, showing a high catalytic performance. Furthermore, manganese dioxide $\left(\mathrm{MnO}_{2}\right)$ was reported to be a promising electrocatalyst which was efficient in ORR activities and could generate a high power output in air cathode MFCs. In addition, a class of Co-MOF-derived dual metal and nitrogen co-doped carbon $(\mathrm{Ni}, \mathrm{Fe}, \mathrm{Zn}$, and $\mathrm{Cu}$ ) catalysts were also studied, which were highly porous, with metal and nitrogen uniformly distributed within the graphite carbon matrix, and exhibited the best ORR performance [18,19]. Along with these, carbides derived from Fe-based MOFs were studied extensively as a potential candidate to replace Pt-based catalysts [20], due to their long-term stability and excellent activity in medium [21-23]. The active sites originating from transition-based MOFs tend to form special pore structures on the carbon matrix $[24,25]$. Various metal organic frameworks $(\mathrm{MOF})$ have been widely exploited as nano-material sources with a controllable structure for electrochemical equipment [26-28]. Lou's group found that $\mathrm{N}$-doped CNTs can be transformed by the precursor zif-67 possessing high electrochemical catalytic activity after carbonization in $\mathrm{H}_{2}$ atmosphere [29]. The precursors of $\mathrm{N}$-sources mainly concentrate on polyaniline, thiourea, carbamide, and polypyrrole. Many researchers also showed immense enthusiasm for introducing other heteroatoms (S, P, B) into MOFs. Among them, the sulfur-doped catalyst was more positively correlated with ORR activity, compared with nitrogen. As the sulfur atom has a larger radius, it could bring some chemical structural defects of the carbon matrix accelerating electron transfer and oxygen adsorption [30,31]. For example, Liu's group [32] synthesized $\mathrm{N}$ and S co-doping porous carbon materials decorated with $\mathrm{FeS}$ and demonstrated the catalysts own prominent ORR activity, favorable stability, and excellent tolerance to methanol. Wang et al. [33] proved that FeS and $\mathrm{Fe}_{9} \mathrm{~S}_{10}$ nanoparticles are essential for ORR. These studies confirm that FeS nanoparticles, as a kind of material introducing $\mathrm{Fe}, \mathrm{S}$, and $\mathrm{N}$ into the carbon matrix, can significantly enhance ORR activity and provide a wider idea and prosperity for developing materials which could replace precious metal-based electrocatalysis.

Considering the catalytic advantages of the type just described, many research groups have focused their attention on the exploration of using transition metal-based catalysts such as iron, cobalt, and manganese with low prices and large amounts available to improve the cathode performance of MFC. In particular, iron-based catalysts are currently the ones used extensively in MFC equipment [34-41]. Carlo's group designed a kind of Fe-N-C oxygen reduction reaction catalyst for microbial fuel cells. Tang's group reported the synthesis of a series of transition metal-based catalysts, namely $\mathrm{M} / \mathrm{CoNC}$, and that corresponding equipment (MFC) achieved a remarkable power density and outstanding durability.

Herewith, we obtained a batch of catalysts named Fe/S@N/C-x ( $x=0.5,0.33,0.25)$. A series of precursors (Fe-encapsulated ZIF-8 carbon materials) were directly synthesized, and the content of Fe was controlled in the precursor by adjusting the proportion of Fe and $\mathrm{Zn}$ of the raw material, 
followed by the introduction of a certain amount of thiourea as a sulfur source under the atmosphere of $1000^{\circ} \mathrm{C}$. In the preparation process, $\mathrm{Zn}$ was removed at a high temperature $\left(1000{ }^{\circ} \mathrm{C}\right)$ and then etched by $\mathrm{HCl}$. The obtained Fe/S@N/C- 0.5 catalyst had a regular structure containing both large numbers of micropores and mesopores, and Fe, N, S uniformly distributed among the material. $\mathrm{FeS}$ is the main phase which was investigated and characterized via XRD and XPS. The Fe, N, and S co-doped Fe/S@N/C-0.5 catalyst exhibits surprising ORR activity in alkaline and neutral phosphate buffered saline(PBS) media, with a remarkable reduction potential at $0.861 \mathrm{~V}$ (vs. RHE) in $0.1 \mathrm{M} \mathrm{KOH}$ solution and $-0.03 \mathrm{~V}$ (vs. SCE) in the PBS solution. The performance of microbial fuel cells (MFCs) employing the Fe/S@N/C-0.5 as a cathode catalyst was tested as well. We confirm that the prepared Fe/S@N/C-0.5 could greatly improve the performance of microbial fuel cells (MFCs), and the Fe/S@N/C-0.5-MFC possesses larger energy and power density compared with Pt/C-MFC under the same conditions.

\section{Experimental}

\subsection{Sample Preparation}

This section simply gives a brief introduction on how to acquire the $\mathrm{Fe}, \mathrm{N}$, and $\mathrm{S}$ co-doped $\mathrm{Fe} / \mathrm{S} @ \mathrm{~N} / \mathrm{C}-\mathrm{x}(\mathrm{x}=0.5,0.33,0.25)$ catalyst. The Fe/S@N/C-x $(\mathrm{x}=0.5,0.33,0.25)$ catalyst, derived from porous metal organic framework-encapsulated iron (Fe-ZIF-8), is easily obtained. This synthesis technique has many advantages, such as being simple to operate and the high purity of products. Firstly, $\mathrm{Fe}^{3+}, \mathrm{Zn}^{2+}$, and 2-methylimidazole are mixed at room temperature using methanol as a solvent to obtain the precursor. After pyrolysis at a high temperature, the original porous framework was maintained and a nano-composite coated with metal nanoparticles (Fe) was obtained. Secondly, the surface agglomerated iron particles and unstable phases were removed by etching with hydrochloric acid, and new pores were formed at the same time. Lastly, at a high temperature, the thiourea was used as the sulfur source to introduce $S$ atoms into materials; simultaneously, the pyrolysis of thiourea produced gas, which further created new pores and improved the porosity.

The series of precursors were synthesized as follows: A solution of $2.975 \mathrm{~g}$ zinc nitrate hexahydrate $\left(\mathrm{Zn}\left(\mathrm{NO}_{3}\right)_{2} \cdot 6 \mathrm{H}_{2} \mathrm{O},>98 \%\right.$, Sigma Aldrich) and ferric chloride $\left(\mathrm{FeCl}_{3}, 1.622 \mathrm{~g}, 0.811 \mathrm{~g}, 0.535 \mathrm{~g}\right.$ vs. $\mathrm{x}=0.5$, $0.33,0.25)$ dissolved in $80 \mathrm{~mL}$ methanol was poured into another solution of $3.284 \mathrm{~g}$ 2-methylimidazole (mlm, $\mathrm{C}_{4} \mathrm{H}_{6} \mathrm{~N}_{2}$, > 99\%, Sigma Aldrich) dissolved in $50 \mathrm{~mL}$ methanol and was stirred for $12 \mathrm{~h}$ at $28^{\circ} \mathrm{C}$. The reaction liquid was concentrated with a vacuum rotary evaporator, and then the crude product was obtained by vacuum filtration. Finally, the russet crude product was washed and purified with a mixture of methanol and acetone in a certain proportion and then dried at $60^{\circ} \mathrm{C}$ by using the vacuum drying oven for $12 \mathrm{~h}$. The prepared precursor was labeled as Fe-ZIF-8.

For the synthesis of Fe/S@N/C-x $(x=0.5,0.33,0.25)$ catalyst, the precursor was placed on a high-temperature ceramic boat in a furnace and carbonized at $1000^{\circ} \mathrm{C}$ for $3 \mathrm{~h}$ in $\mathrm{N}_{2}$ atmosphere with a heating rate of $2.5^{\circ} \mathrm{C} / \mathrm{min}$. After cooling to room temperature, the product was etched in $0.1 \mathrm{M} \mathrm{HCl}$ for $6 \mathrm{~h}$ to remove the unstable components and agglomerated iron particles. Then the powder products were washed with deionized water by repeated centrifugations at $5000 \mathrm{rpm}$ until the supernatant was neutral with a $\mathrm{pH}$ value of 7 . The as etched carbide was mixed well with thiourea by high-energy ball-milling technique, followed by a second calcination at $1000^{\circ} \mathrm{C}$ for $1 \mathrm{~h}$ in a furnace at the same heating rate as the last calcination $\left(2.5^{\circ} \mathrm{C} / \mathrm{min}\right)$. Finally, the product was ground into powder vigorously when cooling it to room temperature. The resultant was referred to as Fe/S@N/C-x $(x=0.5,0.33,0.25)$.

\subsection{Characterization of ORR Activity}

The electrochemical performances of these catalysts were investigated by employing a $\mathrm{CH}$ Instruments $660 \mathrm{E}$ electrochemical workstation with a standard three-electrode structure (Pine Instruments, $5.0 \mathrm{~mm}$ diameter), and all electrochemical ORR tests were carried out at room temperature (RT, $20-25{ }^{\circ} \mathrm{C}$ ). The catalyst ink was prepared by ultrasonically dispersing catalyst $(5 \mathrm{mg})$ into $80 \mu \mathrm{L}$ deionized water, $900 \mu \mathrm{L}$ isopropanol, and $20 \mu \mathrm{L}$ nafion solution $(5 \mathrm{wt} . \%)$ for at least $30 \mathrm{~min}$. 
The catalyst thin film was gained by removing $21 \mu \mathrm{L}$ of catalyst ink on the electrode with a pipette. The three-electrode structure was composed with the glassy carbon working electrode (with various prepared catalysts), a platinum electrode (the counter electrode), and a $\mathrm{Hg} / \mathrm{HgO}$ electrode (reference electrode). The electrode was polished and cleaned according to the instructions of the rotating disc electrode (Pine Instruments): Before the test, the glassy carbon electrodes should be polished with a $0.05 \mu \mathrm{m} \mathrm{Al}{ }_{2} \mathrm{O}_{3}$ particle-suspension on a moistened polishing cloth (Buehler, Micro-Cloth) in a "figure eight" pattern for four minutes to a mirror finish. The polished electrode was rinsed well with nanopure water, sonicated for four minutes in nanopure water, rinsed well again, and then dried at room temperature in air for at least $20 \mathrm{~min}$ before use. Cyclic voltammetry curves were obtained in $\mathrm{O}_{2}$-saturated $0.1 \mathrm{M} \mathrm{KOH}$ solution at $50 \mathrm{mV} / \mathrm{s}$, and linear sweep voltammetry curves were run at a scan rate of $5 \mathrm{mV} / \mathrm{s}$ with rotations at 400, 800, 1200, 1600, and $2000 \mathrm{rpm}$, respectively. In order to evaluate methanol tolerance, the chronoamperometric curves were received in the $\mathrm{O}_{2}$-saturated solution added with methanol $(3 \mathrm{M})$. The long-time stability was tested at $-0.4 \mathrm{~V}(\mathrm{vs} . \mathrm{Hg} / \mathrm{HgO})$ with a rotating rate of $1600 \mathrm{rpm}$ for $20,000 \mathrm{~s}$. In this work, the potential values obtained from all tests in alkaline electrolytes were converted by the calculation to the RHE scale using this transformation equation: $\mathrm{E}(\mathrm{RHE})=\mathrm{E}$ $(\mathrm{Hg} / \mathrm{HgO})+0.866 \mathrm{~V}$ in $0.1 \mathrm{M} \mathrm{KOH}$ solution.

Herein, the further work and improvement about charge transfer numbers and the kinetic parameters of ORR were operated with the help of the Koutecky-Levich (K-L) equation which is exhibited in Formulas (1) and (2).

$$
\begin{gathered}
\frac{1}{J}=\frac{1}{J_{K}}+\frac{1}{J_{L}}=\frac{1}{B \omega^{1 / 2}}+\frac{1}{J_{K}} \\
B=0.2 n F C_{0} D_{0} \frac{2}{3} V^{-\frac{1}{6}}
\end{gathered}
$$

where $J$ indicates the measured current density, $J_{K}$ shows the kinetic current density, and $J_{L}$ represents the diffusion limiting current density. $\omega$ is the rotating speed of $\operatorname{RDE}(\mathrm{rpm}), C\left(1.2 \cdot 10^{-3} \mathrm{~cm}^{2} \cdot \mathrm{L}^{-1}\right)$ is the oxygen concentration of $0.1 \mathrm{M} \mathrm{KOH}$ electrolyte, $D\left(1.9 \times 10^{-5} \mathrm{~cm}^{2} \cdot \mathrm{S}^{-1}\right)$ is the diffusion coefficient of $\mathrm{O}_{2}$ for $0.1 \mathrm{M} \mathrm{KOH}$ solution, and $V\left(1.13 \times 10^{-3} \mathrm{~cm}^{2} \cdot \mathrm{S}^{-1}\right)$ is the kinetic viscosity of the electrolyte for $0.1 \mathrm{M} \mathrm{KOH}$ solution, while $F\left(96485 \mathrm{C} \cdot \mathrm{mol}^{-1}\right)$ is the Faraday constant and $n$ is the calculated charge transfer number.

\subsection{Construction of MFC Equipment}

\subsubsection{Air Cathode Composition}

Figure 1 reveals a schematic diagram of the assembled MFC equipment with a carbon felt anode and Fe/S@N/C-0.5 catalyst-loaded carbon paper cathode. The cathode consists of a carbon base layer, catalyst layer, and a total of four PTFE diffusion layers which are directly exposed to the air. The carbon base layer was formed by applying a mixture of carbon black and 40\% PTFE emulsion to one side of the carbon paper and then placing the piece of carbon paper on a high-temperature ceramic plate in a pre-heated furnace at $370^{\circ} \mathrm{C}$ for about $20-30 \mathrm{~min}$. After cooling the carbon paper to room temperature, a total of four PTFE diffusion layers were obtained by repeating the operation below four times: applying one coat of $60 \%$ PTFE emulsion in a uniform fashion to the previously coated side and then leaving it in a furnace preheated to $370{ }^{\circ} \mathrm{C}$ for about $10-15 \mathrm{~min}$. Finally, a paste-like mixture of catalyst, deionized water, isopropanol, and naphthol was uniformly applied on the other side of the carbon paper and the coating was allowed to air dry for at least $24 \mathrm{~h}$. The mass loading of the catalyst was $0.5 \mathrm{mg} / \mathrm{cm}^{2}$. 


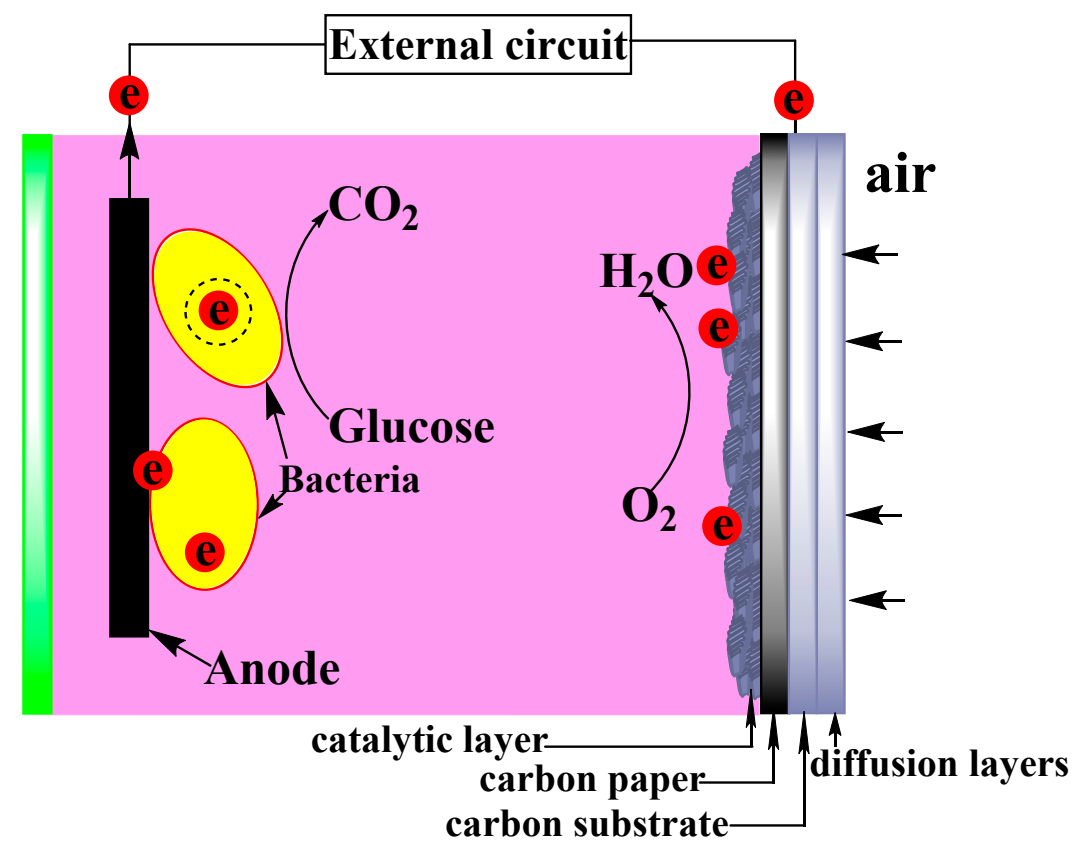

Figure 1. Schematic diagram of assembled microbial fuel cell (MFC) equipment with carbon felt anode and Fe/S@N/C-0.5 catalyst-loaded carbon paper cathode.

\subsubsection{Construction and Operation of MFC}

The bacteria in this paper are facultative anaerobic mixed bacteria, which are derived from oil-bearing sludge in the Jianghan oilfield. Firstly, oily sludge was placed in a sealed container under $30{ }^{\circ} \mathrm{C}$ for a week and the supernatant was obtained (Figure 2a supporting information). Then, an appropriate amount of supernatant was removed with a pipette and mixed with glucose solution at a ratio of 1:5, and the mixture was transparent at the beginning. We could develop bacteria based on this mixture in an incubator chamber at $37^{\circ} \mathrm{C}$. Finally, as shown in Figure $2 b, c$, the bacteria used in the microbial fuel cell experiment in this paper were obtained, and the culture medium containing the bacteria was visibly turbid.
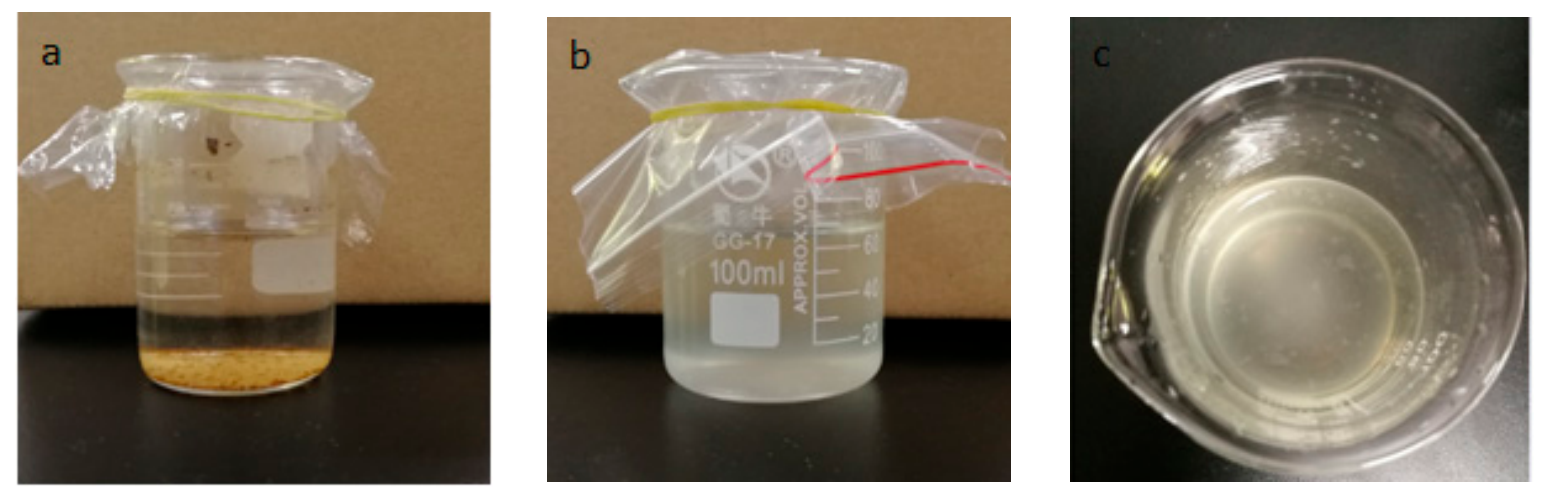

Figure 2. (a) The supernatant of oily sludge. $(\mathbf{b}, \mathbf{c})$ Culture medium containing the bacteria.

We structured the single-chamber microbial fuel cells of the air cathode which was inoculated with oilfield produced water for investigating the performance of the microbial fuel cell (MFC) employing Fe/S@N/C-0.5 as a cathode catalyst. Two completely consistent MFC equipment sets served in experiments which were both about $3 \times 3 \times 4 \mathrm{~cm}$ with $28 \mathrm{~mL}$ effective volume. The two MFC devices with $1000 \Omega$ external resistance employed carbon paper cathodes which were supported with Fe/S@N/C-0.5 catalysts and 20\% Pt-C respectively (denoted as Fe/S@N/C-0.5-MFC and 20\% Pt/C-MFC). 
Two circular carbon felts were used as anodes for these two MFCs. The felts were successively soaked in acetone solution, $1 \mathrm{M}$ hydrochloric acid solution, and $5 \mathrm{M}$ nitric acid solution for $10 \mathrm{~h}$, then washed with deionized water, and finally dried in the oven at $180^{\circ} \mathrm{C}$ for $8 \mathrm{~h}$. Hydrophilic treatments facilitated the adhesion of bacteria on the surface of anodes' carbon felt. Oilfield-produced water was used as an inoculum. Table 1 is the formulation of the glucose solution which includes glucose $(1 \mathrm{~g} / \mathrm{L})$, phosphate buffered saline ( $50 \mathrm{mmol}, \mathrm{pH}=7.2$ ), vitamin solutions $(5 \mathrm{~mL} / \mathrm{L})$, and mineral solutions $(12.5 \mathrm{~mL} / \mathrm{L})$. The formulations of vitamin and mineral elements are exhibited in Tables 2 and 3, respectively. During the operation of $\mathrm{MFC}$, the temperature was maintained at $30^{\circ} \mathrm{C}$ by using an incubator chamber. After the anode biofilm of a microbial fuel cell matured, the polarization curves, power density curves, and output voltage curves were recorded.

Table 1. Formulation of glucose solution.

\begin{tabular}{cc}
\hline Constituent & Concentration \\
\hline glucose & $1 \mathrm{~g} / \mathrm{L}$ \\
\hline PBS (phosphate buffered saline) & $50 \mathrm{mmol} / \mathrm{L}$ \\
\hline vitamin & $5 \mathrm{~mL} / \mathrm{L}$ \\
\hline minerals & $12.5 \mathrm{~mL} / \mathrm{L}$ \\
\hline
\end{tabular}

Table 2. Formulation of vitamin solution.

\begin{tabular}{|c|c|c|c|}
\hline Vitamin & Concentration (mg/L) & Vitamin & Concentration $(\mathrm{mg} / \mathrm{L})$ \\
\hline biotin & 2 & nicotinic acid & 5 \\
\hline folic acid & 2 & vitamin b12 & 0.1 \\
\hline $\begin{array}{c}\text { pyridoxine } \\
\text { hydrochloride }\end{array}$ & 10 & $\begin{array}{l}\text { DL-calcium } \\
\text { pantothenate }\end{array}$ & 5 \\
\hline $\begin{array}{c}\text { thiamine } \\
\text { hydrochloride }\end{array}$ & 5 & p-aminobenzoic acid & 5 \\
\hline riboflavin & 5 & lipoic acid & 5 \\
\hline
\end{tabular}

Table 3. Formulation of trace mineral element solution.

\begin{tabular}{cc}
\hline Mineral & Concentration $(\mathrm{mg} / \mathrm{L})$ \\
\hline $\mathrm{NaCl}$ sodium chloride & 1 \\
\hline $\mathrm{CaCl}_{2}$ calcium chloride & 0.08 \\
\hline $\mathrm{MgSO}_{4} \cdot 7 \mathrm{H}_{2} \mathrm{O}$ magnesium sulfate heptahydrate & 6.14 \\
\hline $\mathrm{MgSO}_{4} \cdot \mathrm{H}_{2} \mathrm{O}$ magnesium sulfate monohydrate & 0.56 \\
\hline $\mathrm{ZnSO}_{4} \cdot 7 \mathrm{H}_{2} \mathrm{O}$ zinc sulfate heptahydrate & 0.27 \\
\hline $\mathrm{FeSO}_{4} \cdot 7 \mathrm{H}_{2} \mathrm{O}$ ferrous sulfate heptahydrate & 0.1 \\
\hline $\mathrm{CuSO}_{4} \cdot 5 \mathrm{H}_{2} \mathrm{O}$ copper pentahydrate sulfate & 0.01 \\
\hline
\end{tabular}

\section{Results and Discussion}

The characterization of ORR activity for as-prepared Fe/S@N/C-x catalysts was estimated in $\mathrm{O}_{2}$-saturated $0.1 \mathrm{M} \mathrm{KOH}$ solution, respectively. At a scale of $0.2-1.0 \mathrm{~V}$ (vs. RHE), the cyclic voltammetry curves of Fe/S@N/C-x catalysts (Figure 3a) all had a distinct oxygen electro-reduction peak corresponding to a significantly larger current. Those peaks were in the order of Fe/S@N/C-0.25 $(\mathrm{E}(\mathrm{RHE})=0.727 \mathrm{~V})<\mathrm{Fe} / \mathrm{S} @ \mathrm{~N} / \mathrm{C}-0.33(\mathrm{E}(\mathrm{RHE})=0.809 \mathrm{~V})<\mathrm{Fe} / \mathrm{S} @ \mathrm{~N} / \mathrm{C}-0.5(\mathrm{E}(\mathrm{RHE})=0.861 \mathrm{~V})$, revealing the $\mathrm{Fe} / \mathrm{S} @ \mathrm{~N} / \mathrm{C}-0.5$ catalyst showed the most excellent ORR activity which was beyond the commercial Pt-C catalyst $(\mathrm{E}(\mathrm{RHE})=0.836 \mathrm{~V})$ [42]. Figure 3b,c demonstrates Linear sweep voltammogram(LSV)curves 
of Fe/S@N/C-x catalysts operated on RDE to further acquire the four-electron selectivity and kinetic current information, with $20 \% \mathrm{Pt}-\mathrm{C}$ as a reference. The sweep rate at various rotating speeds was $5 \mathrm{mV} / \mathrm{s}$. The half-wave potential $\left(\mathrm{E}_{1 / 2}\right)$ of the Fe/S@N/C-0.5 catalyst was $0.87 \mathrm{~V}$, which is $0.13 \mathrm{~V}$ and $0.14 \mathrm{~V}$ more than Fe/S@N/C-0.33 and Fe/S@N/C-0.25, respectively, while the half-wave potential $\left(\mathrm{E}_{1 / 2}\right)$ of the Pt-C catalyst was $0.84 \mathrm{~V}$ under the same test conditions. Further, at $1600 \mathrm{rpm}$, the Fe/S@N/C-0.5 catalyst also has a stronger diffusion-limiting current density $\left(J_{L}\right)$ of $6.16 \mathrm{~mA} \cdot \mathrm{cm}^{-1}$, which is 1.21 , 1.85 , and $0.56 \mathrm{~mA} \cdot \mathrm{cm}^{-1}$ more than the $\mathrm{Fe} / \mathrm{S} @ \mathrm{~N} / \mathrm{C}-0.33, \mathrm{Fe} / \mathrm{S} @ \mathrm{~N} / \mathrm{C}-0.25$, and Pt-C catalysts, respectively. In sum, the Fe/S@N/C-0.5 catalyst showed a surprising electro-catalytic activity. Furthermore, by chronoamperometric curve(i-t) tests (Figure 3e), the Fe/S@N/C-0.5 catalyst also showed better long-term stability compared with $\mathrm{Pt} / \mathrm{C}$ at $-0.4 \mathrm{~V}$ (vs. $\mathrm{Hg} / \mathrm{HgO}$ ). The current of Fe/S@N/C-0.5 catalyst decreased by less than $7 \%$ after $20,000 \mathrm{~s}$, while it fell by $30 \%$ in Pt/C. For the methanol tolerance tests (Figure $3 \mathrm{f}$ ), after methanol injection, the current value of the Fe/S@N/C-0.5 catalyst was almost constant with only subtle variations, while it attenuated greatly in $\mathrm{Pt} / \mathrm{C}$.

To better explore the reaction pathway and evaluate the kinetics parameters of the Fe/S@N/C-0.5 catalyst, rotating disk electrode (RDE) test results gave the parameters that depend on the K-L equation. Figure $3 c$ subtly delineates the correlation between the diffusion limiting current density $\left(\mathrm{J}_{\mathrm{L}}\right)$ and the rotational speed. When increasing the rotating rates from 400 to $2000 \mathrm{rpm}$, the diffusion limiting current density increased, pointing to kinetic-limiting behavior for ORR. In Figure 3d, the Koutecky-Levich (K-L) plots are charted with the values of currents at various rotating rates from 400 to $2000 \mathrm{rpm}$, and the result has high linearity. In short, the calculated electron transfer number from the slopes of the K-L plots is 3.89 (average value of various potentials) indicating that the Fe/S@N/C-0.5 catalyst works mainly through a four-electron reduction mechanism approximate to the $\mathrm{Pt} / \mathrm{C}$ catalyst [43].
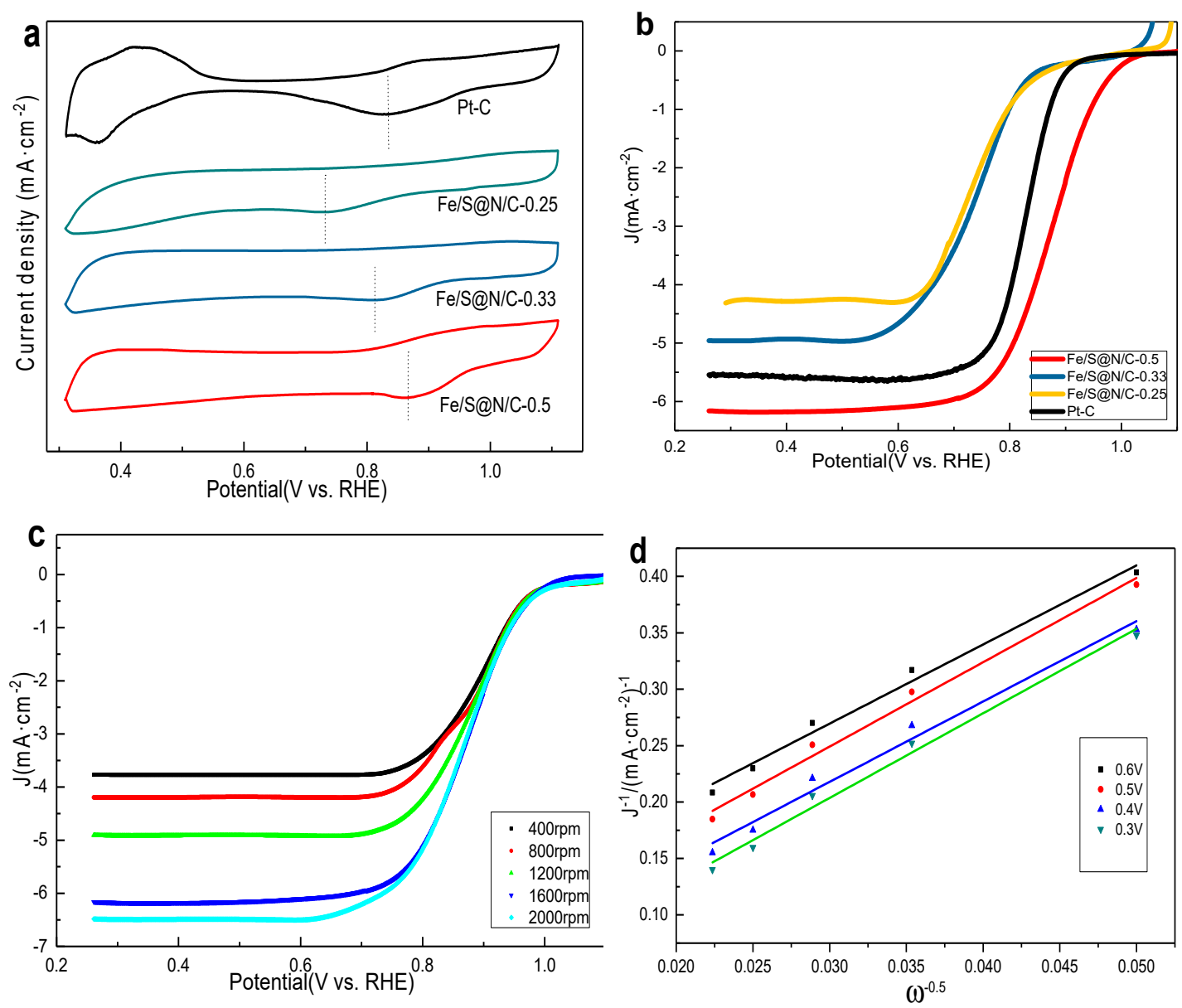

Figure 3. Cont. 

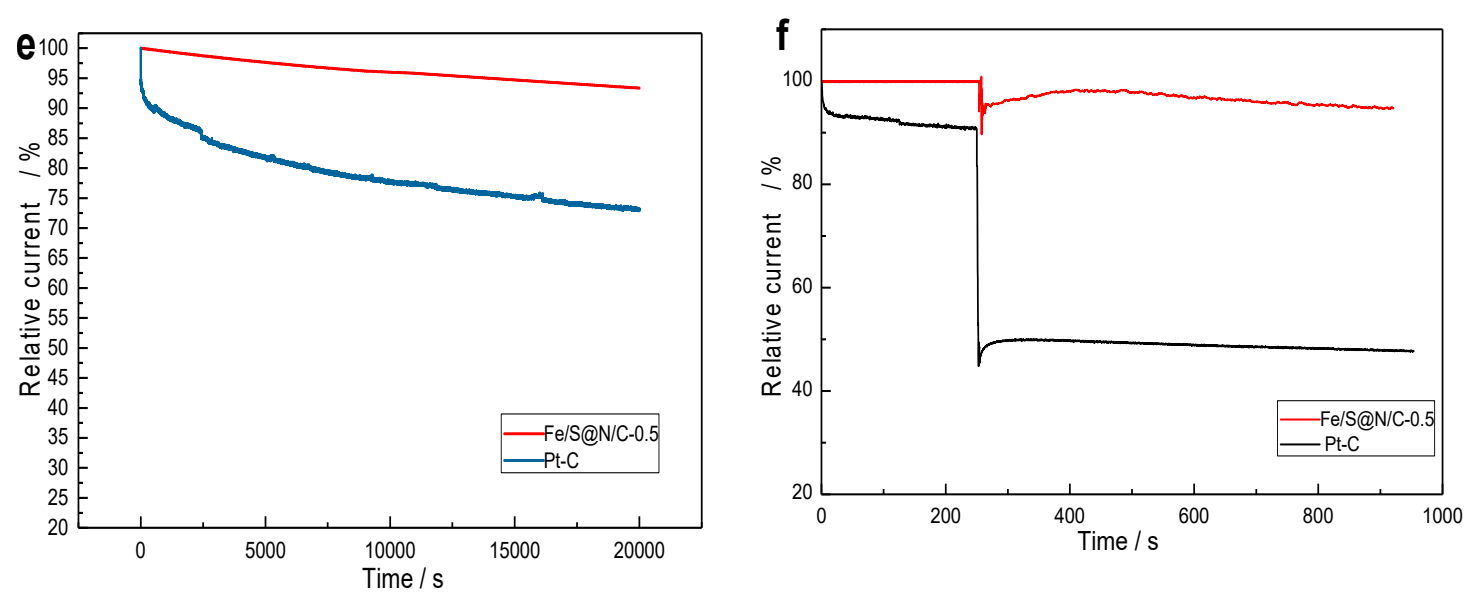

Figure 3. The oxygen reduction reaction (ORR) performance of Fe/S@N/C-x in $0.1 \mathrm{M} \mathrm{KOH}$ solution. (a) CV curves of Fe/S@N/C-x. (b) Linear sweep voltammogram (LSV) curves of Fe/S@N/C-x and 20\% $\mathrm{Pt} / \mathrm{C}$ in $\mathrm{O}_{2}$-saturated $0.1 \mathrm{M} \mathrm{KOH}$ solution at $1600 \mathrm{rpm}$ with a scan rate of $5 \mathrm{mV} / \mathrm{s}$. (c) LSV curves of Fe/S@N/C-0.5 with different rotating rates at a scan rate of $5 \mathrm{mV} / \mathrm{s}$. (d) Koutecky-Levich (K-L) equation of Fe/S@N/C-0.5 with different potentials. (e,f) Stability curves and methanol tolerance curves for $\mathrm{Fe} / \mathrm{S} @ \mathrm{~N} / \mathrm{C}-0.5$ and $20 \% \mathrm{Pt} / \mathrm{C}$ catalysts in $\mathrm{O}_{2}$-saturated $0.1 \mathrm{M} \mathrm{KOH}$ at $1600 \mathrm{rpm}$.

In order to investigate the catalytic activity of Fe/S@N/C-0.5 catalyst on the cathode for MFC, the cyclic voltammetry $(\mathrm{CV})$ curves and LSV measurements were carried out in $0.01 \mathrm{M}$ PBS solution with a pH value of 7 (Figure $4 \mathrm{a}, \mathrm{b}$ supporting information). Traditionally, neutral PBS solutions are used as electrolytes for biological test systems [44]. As a control, the same experiments could also be done for 20\% Pt-C. Figure 4a displays CV curves of Fe/S@N/C-0.5 in $\mathrm{O}_{2}$-saturated (solid line) and $\mathrm{N}_{2}$-saturated (dashed line) 0.01 M PBS solution with commercial 20\% Pt-C (tested in $\mathrm{O}_{2}$-saturated $0.01 \mathrm{M}$ PBS solution) as a reference. It is easy to visually observe the response from the ORR. The Fe/S@N/C-0.5 catalyst represents a pronounced cathodic ORR peak at $-0.03 \mathrm{~V}$ vs. SCE as the PBS solution is saturated with oxygen. In contrast, there is no ORR peak in the nitrogen-saturated electrolyte, indicating that the Fe/S@N/C-0.5 catalyst owns excellent ORR catalytic activity in neutral PBS electrolyte. Rotating disk electrode (RDE) LSV experiments were also conducted in 0.01 M PBS solution for Fe/S@N/C-0.5 catalyst and commercial 20\% Pt-C. The comparisons of the results at $1600 \mathrm{rpm}$ are shown in Figure $4 \mathrm{~b}$. Encouragingly, compared with commercial 20\% Pt-C, there was a more positive onset potential and a stronger limiting current in Fe/S@N/C-0.5 catalyst, which were higher than those of non-noble metal catalysts reported in the recent literature [45], further confirming the excellent ORR performance of the prepared Fe/S@N/C-0.5 catalyst in neutral PBS solution [46].

In order to exploit the electricity generation of Fe/S@N/C-0.5-MFC, the Fe/S@N/C-0.5 catalyst was evaluated in a single-chamber microbial fuel cell of an air cathode for power production and output voltage (Figure 5a,b). The performance of MFC is difficult to directly compare with the results in the literature for many reasons, such as different anode structures, cathode structures, inoculated bacteria strain, components of nutrient solution, and adopted parameters [47]. Therefore, another completely consistent MFC equipment employing the $20 \% \mathrm{Pt}-\mathrm{C}$ as a cathode catalyst was set as a control to clarify that our Fe/S@N/C-0.5 catalyst is a robust catalyst for the oxygen reduction reaction in microbial fuel cells.

The open circuit voltage (OCV) in an MFC is the maximum voltage that could be captured by this power generating units, which is mainly limited by the specific bacterial community and the cathodes. For any power source including MFC, the target is to get the maximum power output, that is, to acquire the strongest current density under the conditions of the highest potential. The output voltage decreases with the decrease of external resistance; therefore, we needed to seek the smallest voltage drop in the process of increasing power density, so as to acquire the maximum power output 
over the current range of interest, while the polarization curve can be employed to characterize the correlation between current and voltage. This curve demonstrates that the MFC equipment possesses a voltage in the range of the current [48].
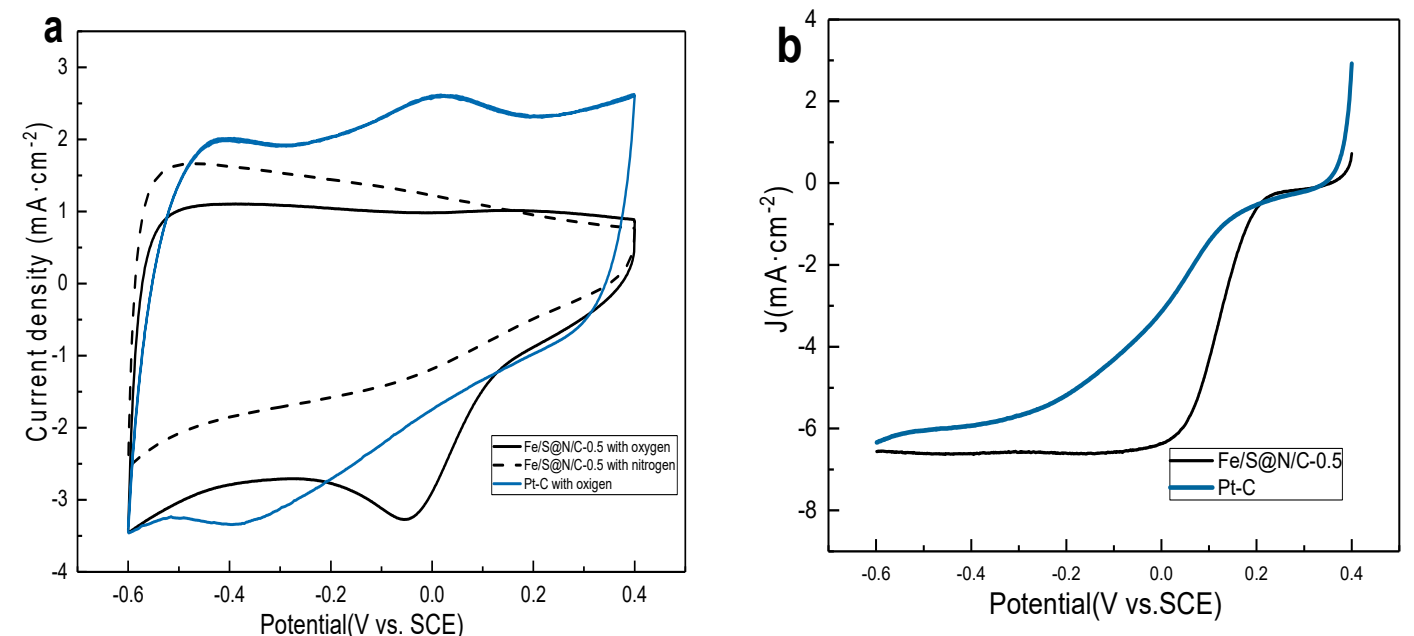

Figure 4. (a) CV curves of Fe/S@N/C-0.5 and 20\% Pt-C in $\mathrm{O}_{2}$ and $\mathrm{N}_{2}$-saturated $0.01 \mathrm{M}$ PBS solution. (b) Linear sweep voltammogram (LSV) curves of Fe/S@N/C-0.5 and 20\% Pt-C in $\mathrm{O}_{2}$-saturated $0.01 \mathrm{M}$ PBS solution at $1600 \mathrm{rpm}$.
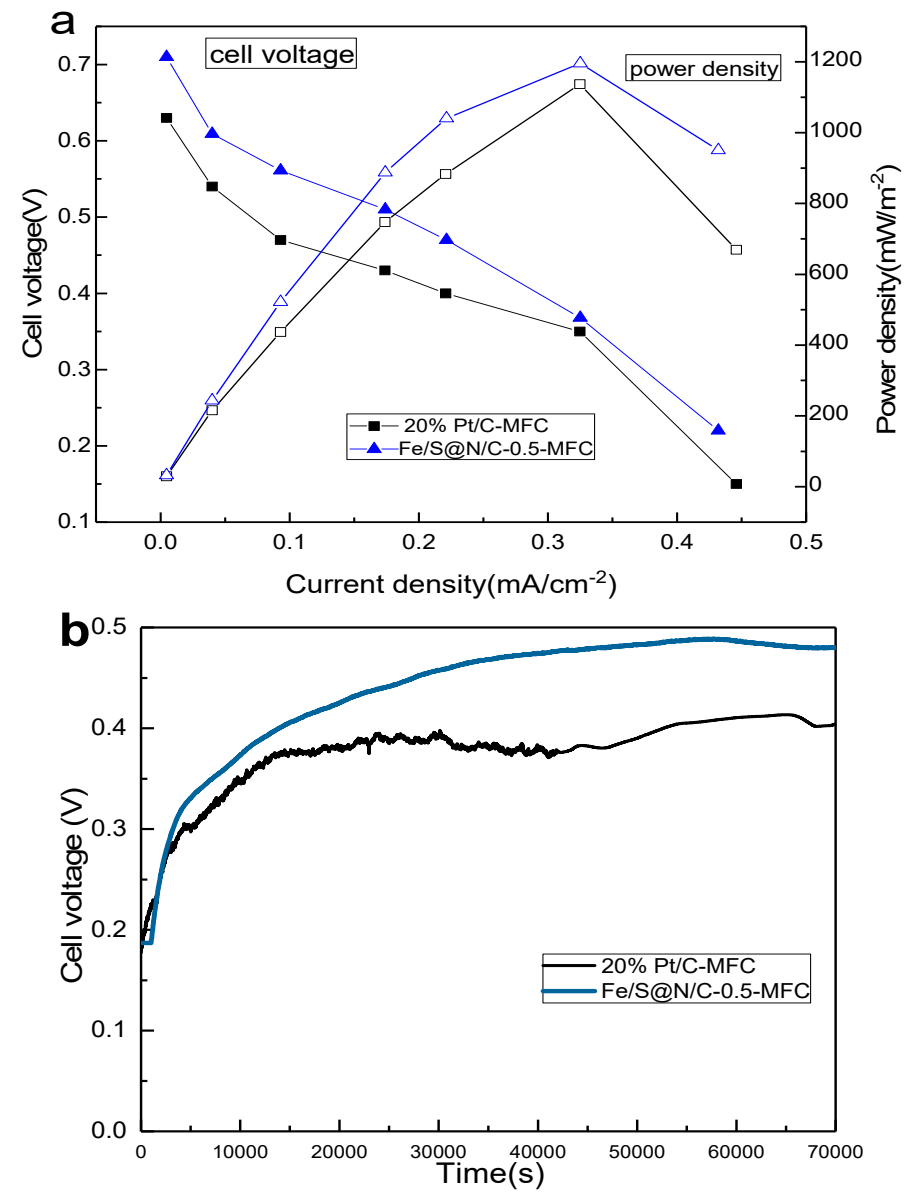

Figure 5. (a) Overall MFC polarization curves and power curves for the $20 \% \mathrm{Pt} / \mathrm{C}$ catalyst and $\mathrm{Fe} / \mathrm{S} @ \mathrm{~N} / \mathrm{C}-0.5$ catalyst. (b) Comparisons of output voltage in the operation of $20 \% \mathrm{Pt} / \mathrm{C}-\mathrm{MFC}$ and $\mathrm{Fe} / \mathrm{S} \mathrm{N} / \mathrm{C}-0.5-\mathrm{MFC}$. 
Overall polarization curves and power curves were operated when the open circuit voltage (OCV) was stable within the $1 \mathrm{mV}$ range (Figure 5a). The Fe/S@N/C-0.5-MFC showed an OCV (0.71 V) that is $0.08 \mathrm{~V}$ superior compared to the Pt/C-MFC. On the whole, the voltage drop of the Fe/S@N/C-0.5-MFC was smaller than that of the $\mathrm{Pt} / \mathrm{C}-\mathrm{MFC}$ as the current density increased. This adds to the evidence that the Fe/S@N/C-0.5-MFC possesses a higher performance [49]. The power density curves prove the same conclusion, the maximum power density of Fe/S@N/C-0.5-MFC reached up to $1196 \mathrm{~mW} / \mathrm{m}^{2}$, while that of Pt/C-MFC was $1137 \mathrm{~mW} / \mathrm{m}^{2}$ under the same circumstances. The Fe/S@N/C-0.5-MFC had a $59 \mathrm{~mW} / \mathrm{m}^{2}$ higher power density compared to Pt/C-MFC. Figure $5 \mathrm{~b}$ exhibits the comparisons of the output voltage of these two devices. After these MFCs operated stably, their output voltage was detected. That value of Fe/S@N/C-0.5-MFC ( 0.47 V) was $90 \mathrm{mV}$ higher than that of Pt/C-MFC $(\sim 0.38 \mathrm{~V})$. The combined abovementioned results indicate that the prepared Fe/S@N/C-0.5 catalyst owns excellent catalytic activity for air cathode MFCs [50].

To further examine the physical properties, especially the crystalline structure of these carbonized materials (Fe/S@N/C-x) and the precursor (Fe-ZIF-8), XRD patterns shown in Figure 6 display a good graphical representation of this. It is observed that structures of the precursor (Fe-ZIF-8) and the initial ZIF-8 rebuilt in our work coordinate well with that of the simulated ZIF-8 (Figure 6a). They all exhibit similar diffraction peaks, implying that no change compared to the crystal structure of pristine ZIF-8 is detected after the introduction of the iron source. For Fe/S@N/C-x, after being doped with thiourea and calcined twice at a high temperature, the original peaks vanish; instead, some new diffraction peaks are created. In the diagram (Figure 6b), these synthesized composites, Fe/S@N/C-0.5 and Fe/S@N/C-0.33, both show typical sharp peaks at around $29.8^{\circ}, 33.7^{\circ}, 43.2^{\circ}$, and $53.2^{\circ}$, coinciding with (110), (112), (114), and (300) of FeS (JCPDS No. 76-0960) respectively, confirming the correct generation of FeS [51]. The diffraction peaks of Fe/S@N/C-0.5 are stronger than those of Fe/S@N/C-0.33, suggesting that Fe/S@N/C-0.5 had better crystallinity of FeS, which is favorable to accelerate the ORR process according to the electrochemical test analysis and results above. In contrast, Figure $6 \mathrm{c}$ shows that the phase of $\mathrm{Fe} / \mathrm{S} @ \mathrm{~N} / \mathrm{C}-0.25$ that shows a poor performance in electrochemical tests is not FeS.

X-ray photoelectron spectroscopy (XPS) was employed to clarify the detailed chemical profiles for all sorts of elements in Fe/S@N/C-x, and the data were plotted in Figures 7 and 8. Survey spectra in Figure 7 confirm the existence of $\mathrm{Fe}, \mathrm{O}, \mathrm{N}, \mathrm{C}$, and $\mathrm{S}$ elements in all $\mathrm{Fe} / \mathrm{S} @ \mathrm{~N} / \mathrm{C}-\mathrm{x}$ samples. The photoelectric peaks of the $\mathrm{N} 1$ s spectrum imply the presences of pyridinic $\mathrm{N}$, pyrrolic $\mathrm{N}$, and graphitic $\mathrm{N}$ [52] with a binding energy center at 398.6, 400.1, and $401.8 \mathrm{eV}$, respectively (Figure 8c supporting information). In Figure 8b, the S2p spectra of Fe/S@N/C-0.5 and Fe/S@N/C-0.33 samples' main crystal phases of FeS could both match well with the C-S-C chemical bonding; the peaks at $163.8 \mathrm{eV}$ and $165.7 \mathrm{eV}$ correspond to S 2p3/2 and S 2p1/2, respectively. The appearance of C-S-C bond confirms that $\mathrm{S}$ atoms were successfully incorporated into the structure of aromatic carbon, the active site of which is believed to be thiophene S [53]. The binding energy of $161 \mathrm{eV}$ is related to FeS, and another peak at $168.2 \mathrm{eV}$ corresponds to SOx. The deconvoluted Fe 2p spectra in Figure 8a show the formation of Fe $2 \mathrm{p} 3 / 2\left(\mathrm{Fe}^{2+} / \mathrm{Fe}^{3+}\right)$ and $2 \mathrm{p} 1 / 2\left(\mathrm{Fe}^{2+} / \mathrm{Fe}^{3+}\right)$ in all Fe/S@N/C-x samples at approximately $711-713$ and $716.5 \mathrm{eV}$, respectively. The powerful interaction between $\mathrm{Fe}^{2+}$ and $\mathrm{S}$ species could give rise to the production of FeS $[54,55]$. It is widely reported that these nanoparticles could be the active sites for ORR performance [56]. For Fe/S@N/C-0.33, an extra weaker peak at $708.4 \mathrm{eV}$ emerges, which is matched with $\mathrm{Fe} / \mathrm{Fe}_{3} \mathrm{C}$. For the last few years, many studies have shown that the catalytic activity could be significantly diminished when $\mathrm{Fe}_{3} \mathrm{C}$ exists [57], and the same is true for aggregate Fe particles. Hence, the Fe/S@N/C-0.33 catalyst displays a weaker ORR performance compared with Fe/S@N/C-0.5, even though their main phases are the same $(\mathrm{FeS})$. As for the $\mathrm{C}$ 1s spectrum of the Fe/S@N/C-0.5 and $\mathrm{Fe} / \mathrm{S} @ \mathrm{~N} / \mathrm{C}-0.33$ samples, the binding energy values of 284,286 , and $286.3 \mathrm{eV}$ are relevant to $\mathrm{C}-\mathrm{C}$, $\mathrm{C}-\mathrm{N} / \mathrm{C}-\mathrm{S} / \mathrm{C}-\mathrm{O}$ and $\mathrm{C}=\mathrm{O} / \mathrm{C}=\mathrm{N}$, respectively (Figure $8 \mathrm{~d}$ ). Additionally, as shown in the table of the proportion for each element (Table 4), the atomic contents of $S$ and Fe are proportional in Fe/S@N/C-0.5, and both are the highest among the three samples. Within a certain concentration range, the ORR activity increased with the increase of the Fe content, and similar conclusions have been reached in 
some previous research [58]. Corresponding to the electrochemical properties tested above, it can be clearly seen that the content of $\mathrm{S}$ also has a positive correlation with the ORR activity. That is, $\mathrm{Fe} / \mathrm{S} @ \mathrm{~N} / \mathrm{C}-0.5(\mathrm{~S} \%=6.63)>\mathrm{Fe} / \mathrm{S} @ \mathrm{~N} / \mathrm{C}-0.5(\mathrm{~S} \%=4.32)>\mathrm{Fe} / \mathrm{S} @ \mathrm{~N} / \mathrm{C}-0.5(\mathrm{~S} \%=3.97)$, and the sum of the contents of $\mathrm{Fe}, \mathrm{N}$, and $\mathrm{S}$ follows this order as well.
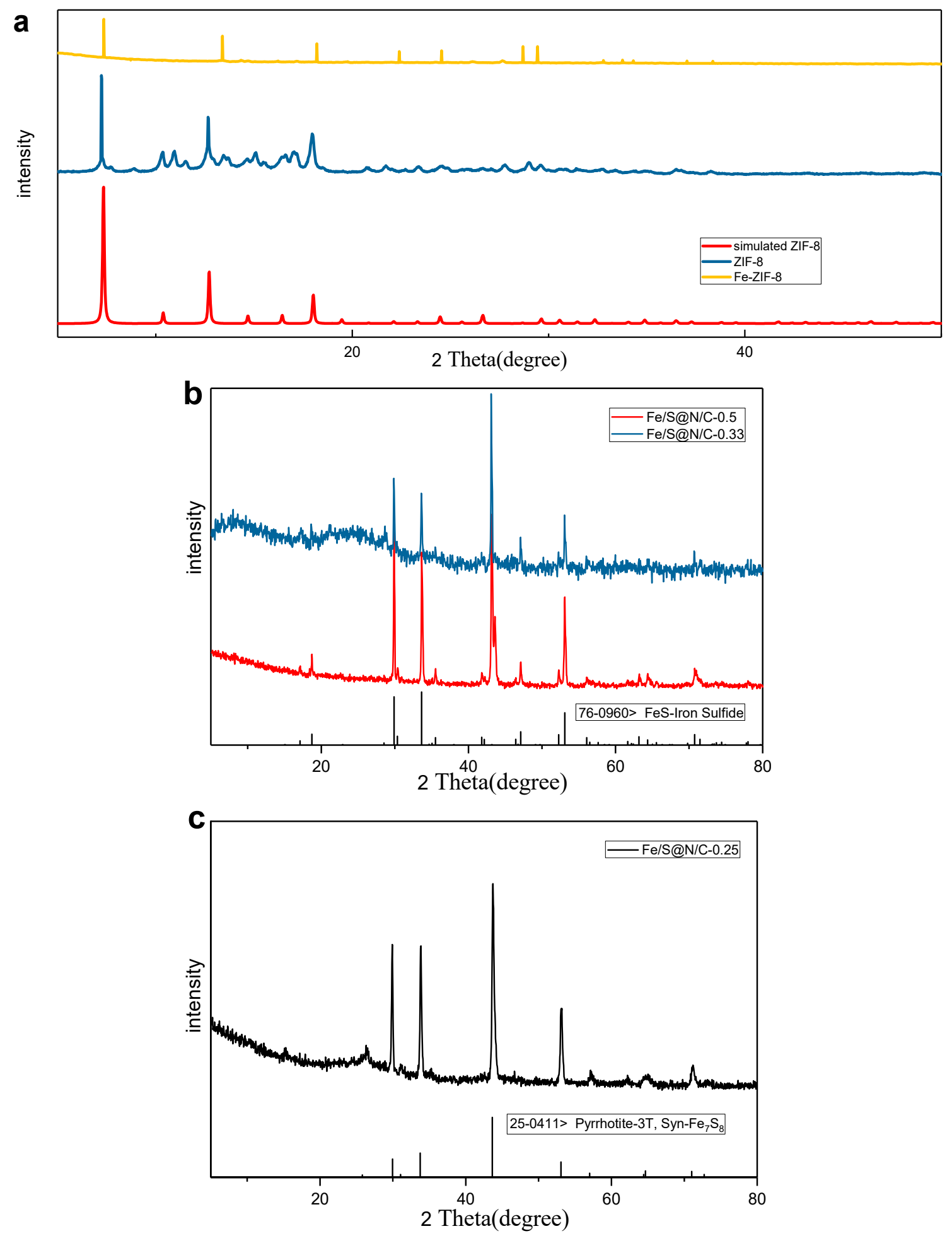

Figure 6. (a) XRD patterns of precursor of Fe/S@N/C-0.5. (b) XRD patterns of Fe/S@N/C-0.5 and $\mathrm{Fe} / \mathrm{S} @ \mathrm{~N} / \mathrm{C}-0.33$. (c) XRD patterns of Fe/S@N/C-0.25. 


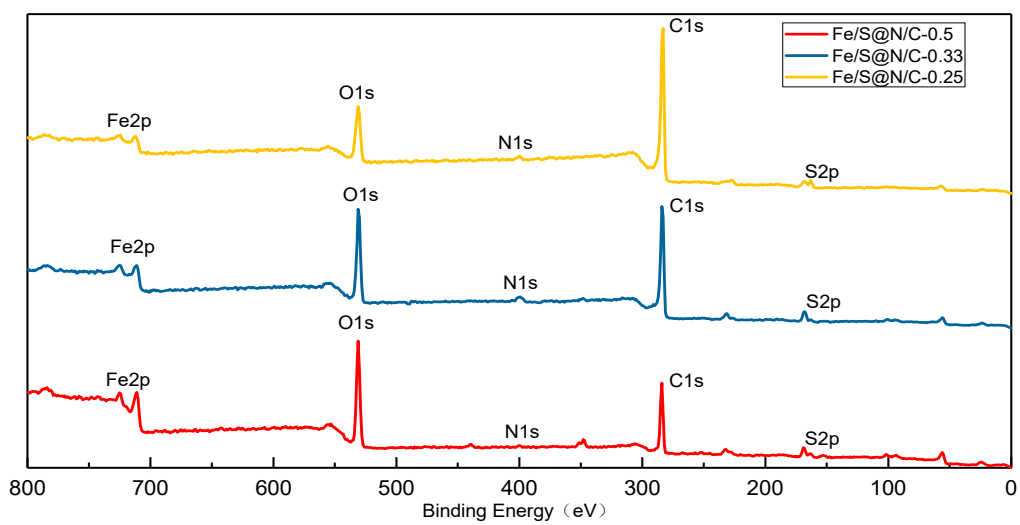

Figure 7. Survey XPS spectrum of Fe/S@N/C-x.

Scanning electron microscopy (SEM), transmission electron microscopy (TEM), and elemental maps of Fe, S, C, and N were employed to probe the structure and morphology of the Fe/S@N/C-0.5 catalyst. As shown in Figure 9a-c, the classical octahedral structure of ZIF-8 [59] remained in Fe-ZIF-8 and Fe/S@N/C-0.5 materials with a uniform size of $\sim 80 \mathrm{~nm}$, confirming that carbonization at a high temperature and modification processes such as $\mathrm{S}$ doping and acid etching could not destroy the original structure of the MOF. According to the SEM images, the surface morphology of the Fe/S@N/C-0.5 catalyst became rough compared with Fe-ZIF-8. No crystalline iron species and aggregated sulfur atoms are found in the TEM image (Figure 9d). Besides, based on the elemental mapping images of $\mathrm{Fe} / \mathrm{S} @ \mathrm{~N} / \mathrm{C}-0.5$ (Figure 9e), it is clear that $\mathrm{Fe}, \mathrm{N}, \mathrm{S}$, and $\mathrm{C}$ are successfully dispersed uniformly in the material. These analyses correspond to the atomic-level dispersion of $\mathrm{Fe}, \mathrm{S}$, and $\mathrm{N}$ in Fe/S@N/C-0.5 materials and could promote the ORR activity $[60,61]$.
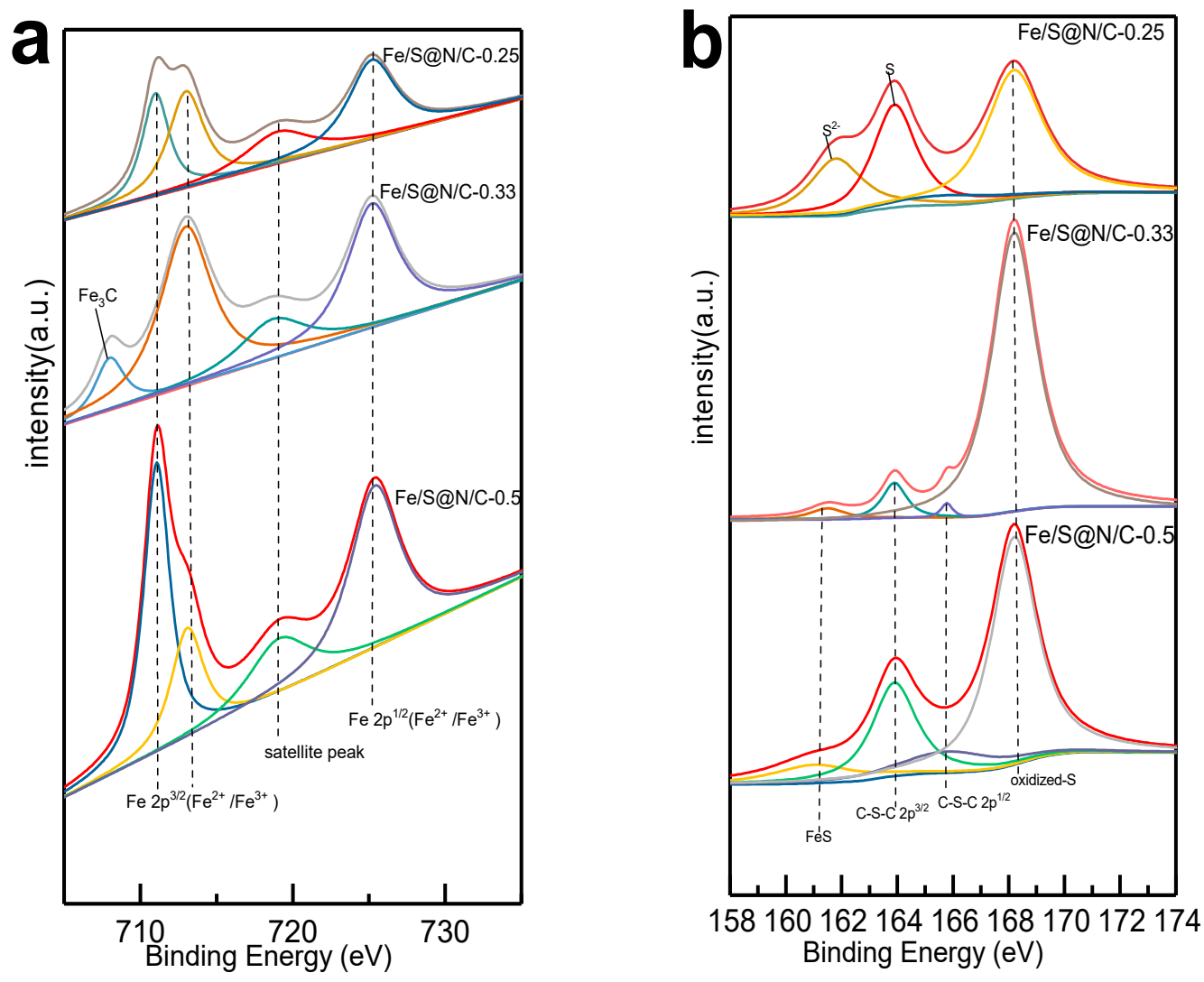

Figure 8. Cont. 

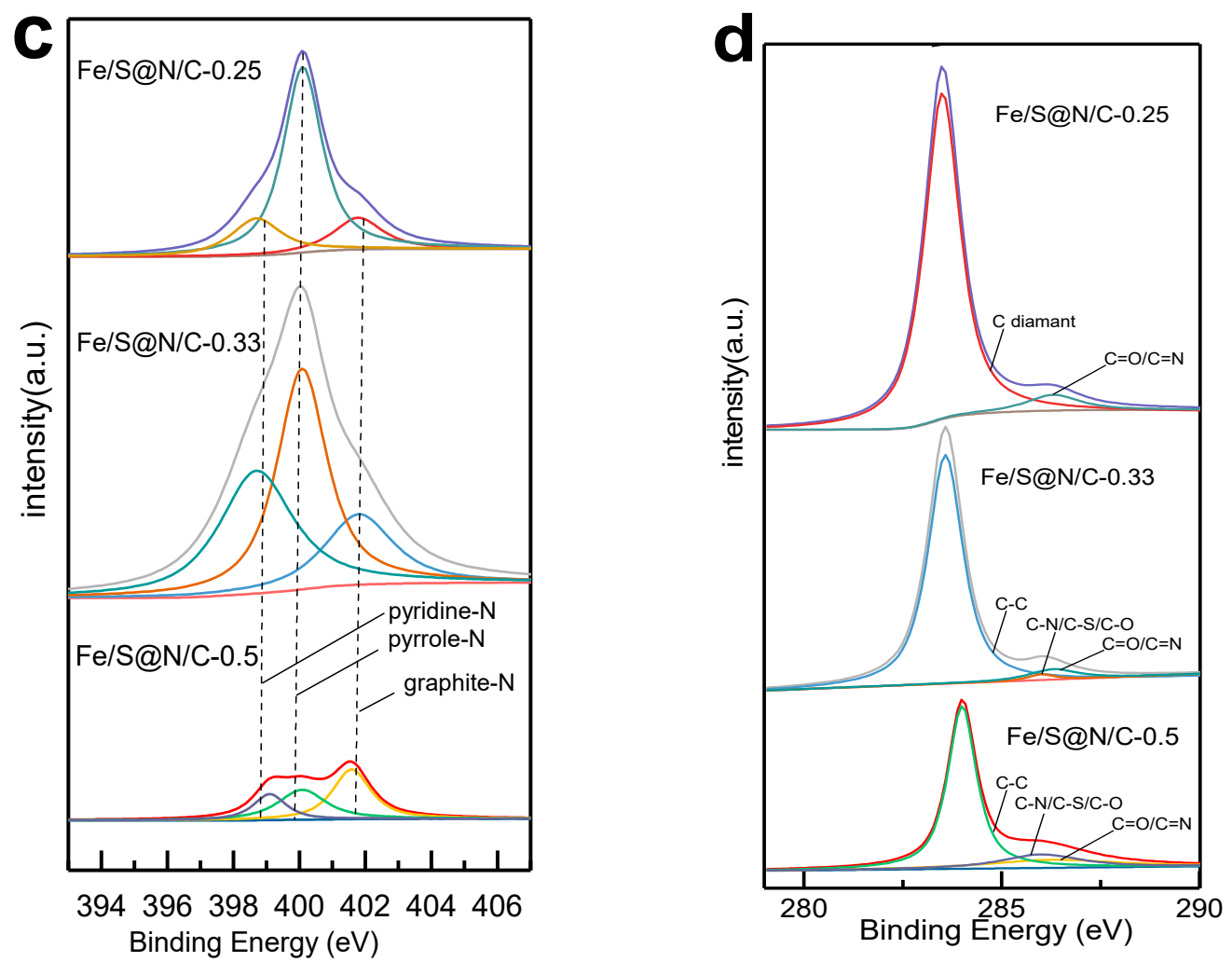

Figure 8. (a) High-resolution Fe 2p XPS spectrum of Fe/S@N/C-x. (b) High-resolution S2p N1s XPS spectrum of Fe/S@N/C-x. (c) High-resolution N1s XPS spectrum of Fe/S@N/C-x. (d) High-resolution C1s XPS spectrum of Fe/S@N/C-x.

Table 4. Proportion of each element for Fe/S@N/C-x.

\begin{tabular}{ccccc}
\hline Samples & $\mathbf{C ~ ( \% )}$ & $\mathbf{N ~ ( \% )}$ & $\mathbf{S ~ ( \% )}$ & Fe (\%) \\
\hline $\mathrm{Fe} / \mathrm{S} @ \mathrm{~N} / \mathrm{C}-0.5$ & 50.47 & 0.7 & 6.63 & 6.2 \\
\hline $\mathrm{Fe} / \mathrm{S} @ \mathrm{~N} / \mathrm{C}-0.33$ & 64.72 & 3.59 & 4.32 & 3.87 \\
\hline $\mathrm{Fe} / \mathrm{S} @ \mathrm{~N} / \mathrm{C}-0.25$ & 76.85 & 1.89 & 3.97 & 2.62 \\
\hline
\end{tabular}
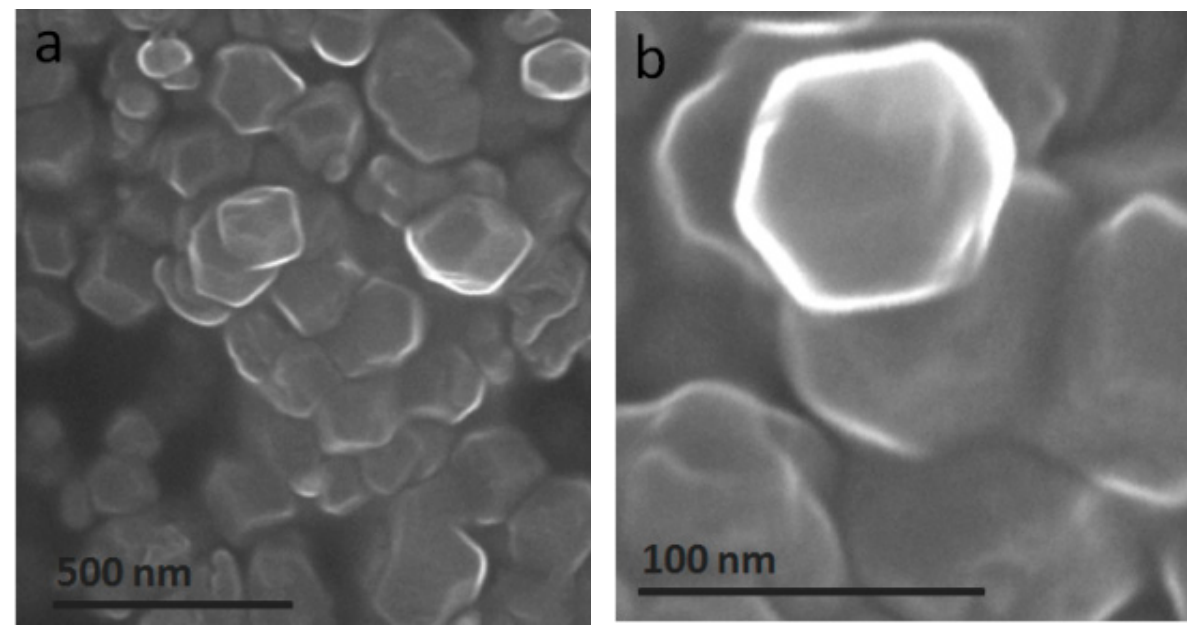

Figure 9. Cont. 

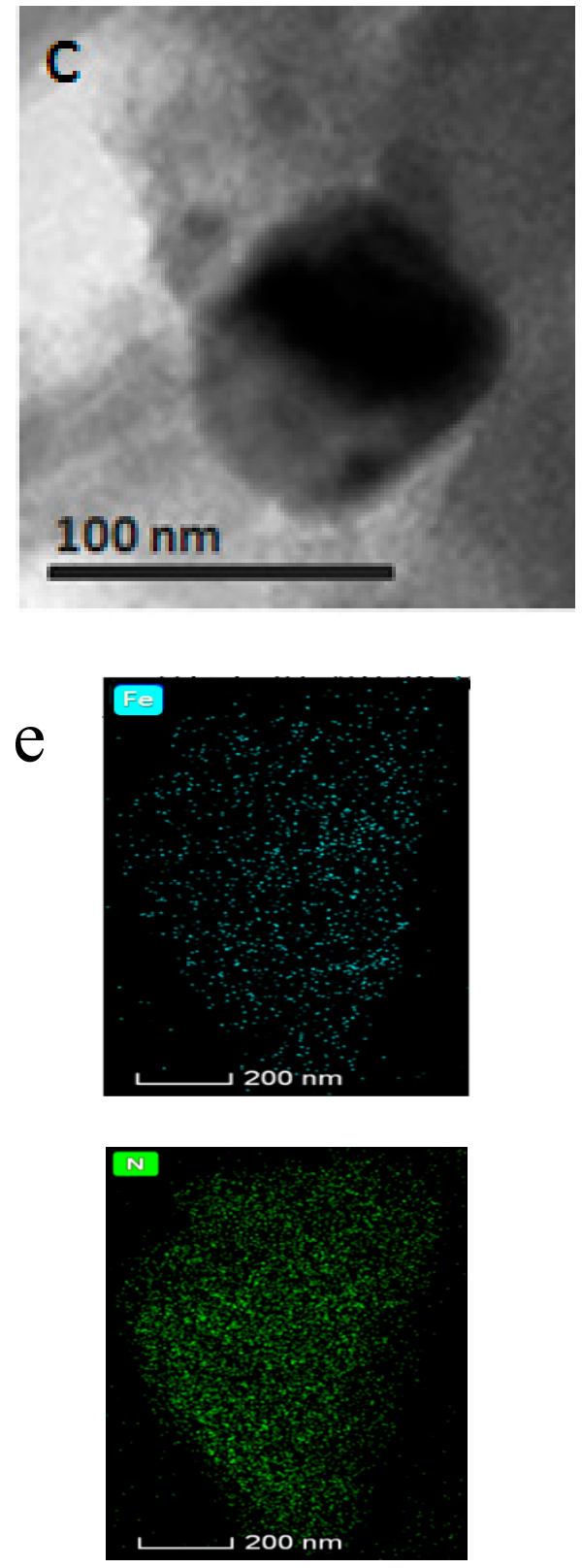
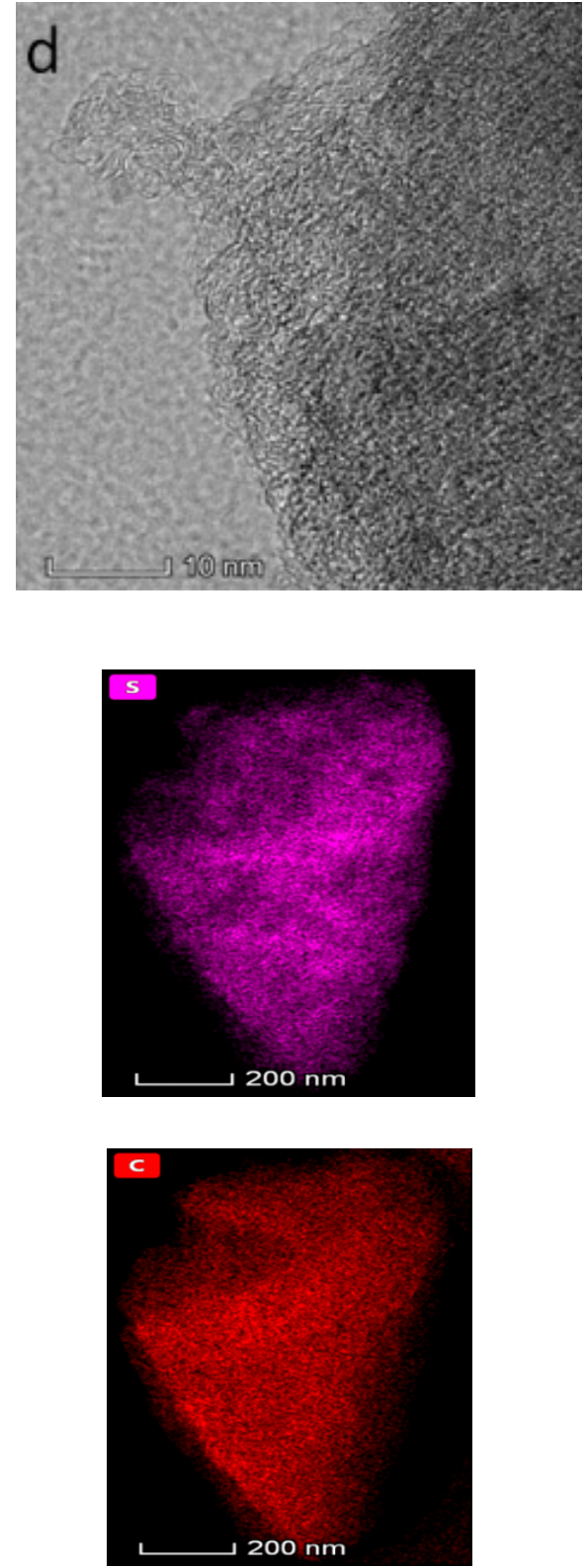

Figure 9. (a,b) SEM images of Fe-ZIF-8. (c) SEM images of Fe/S@N/C-0.5. (d) TEM of Fe/S@N/C-0.5. (e) HAADF-STEM mapping of Fe/S@N/C-0.5.

According to the $\mathrm{N}_{2}$ adsorption/desorption measurements at $-196{ }^{\circ} \mathrm{C}, \mathrm{Fe} / \mathrm{S} @ \mathrm{~N} / \mathrm{C}-0.5$ is quite different from the other two Fe/S@N/C-x $(0.33,0.25)$ in terms of the surface pore characteristics. Table 5 shows the details. The BET and Langmuir surface areas of the Fe/S@N/C-0.5 catalyst are $598 \mathrm{~m}^{2} / \mathrm{g}$ and $704 \mathrm{~m}^{2} / \mathrm{g}$ respectively; both of them are highest compared with the other two Fe/S@N/C-x $(0.33,0.25)$. As the graph (Figure 10a) shows, the $\mathrm{N}_{2}$ sorption isotherms of Fe/S@N/C-0.5 material contain the characteristics of typical type I and type IV isotherms [62], which shows a sharp increase in the low relative pressure and an obvious hysteresis loop in higher relative pressure, illustrating that mesopores (2-50 $\mathrm{nm}$ in diameter) and microporous (less than 2 nanometers in diameter) structures are present. By using the t-plot method and the Barrett-Joyner-Halenda $(\mathrm{BJH})$ model, the pore size distribution curves were generated (Figure 10b supporting information) and further illustrate that the Fe/S@N/C-0.5 material contains a mass of micropores and mesopores. As seen in Table 5, it is clear that the pore diameters of the Fe/S@N/C-0.5 material are mainly distributed around $1.8 \mathrm{~nm}$ (micropores) and $7.5 \mathrm{~nm}$ 
(mesopores). Unlike the Fe/S@N/C-0.5, the Fe/S@N/C-0.33 and Fe/S@N/C-0.25 contain only micropores the diameters of which are $1.8 \mathrm{~nm}$.

Table 5. BET and Langmuir surface area and pore diameter of Fe/S@N/C-x.

\begin{tabular}{ccccc}
\hline Samples & $\mathbf{S}_{\text {BET }}\left(\mathbf{m}^{\mathbf{2}} \mathbf{g}\right)$ & S $_{\text {Langmuir }}\left(\mathbf{m}^{\mathbf{2}} / \mathbf{g}\right)$ & D $_{\text {micropore }}(\mathbf{n m})$ & D $_{\text {mesopore }}(\mathbf{n m})$ \\
\hline Fe/S@N/C-0.5 & 598 & 704 & 1.8 & 7.5 \\
\hline Fe/S@N/C-0.33 & 367 & 582 & 1.8 & - \\
\hline Fe/S@N/C-0.25 & 209 & 311 & 1.8 & - \\
\hline
\end{tabular}
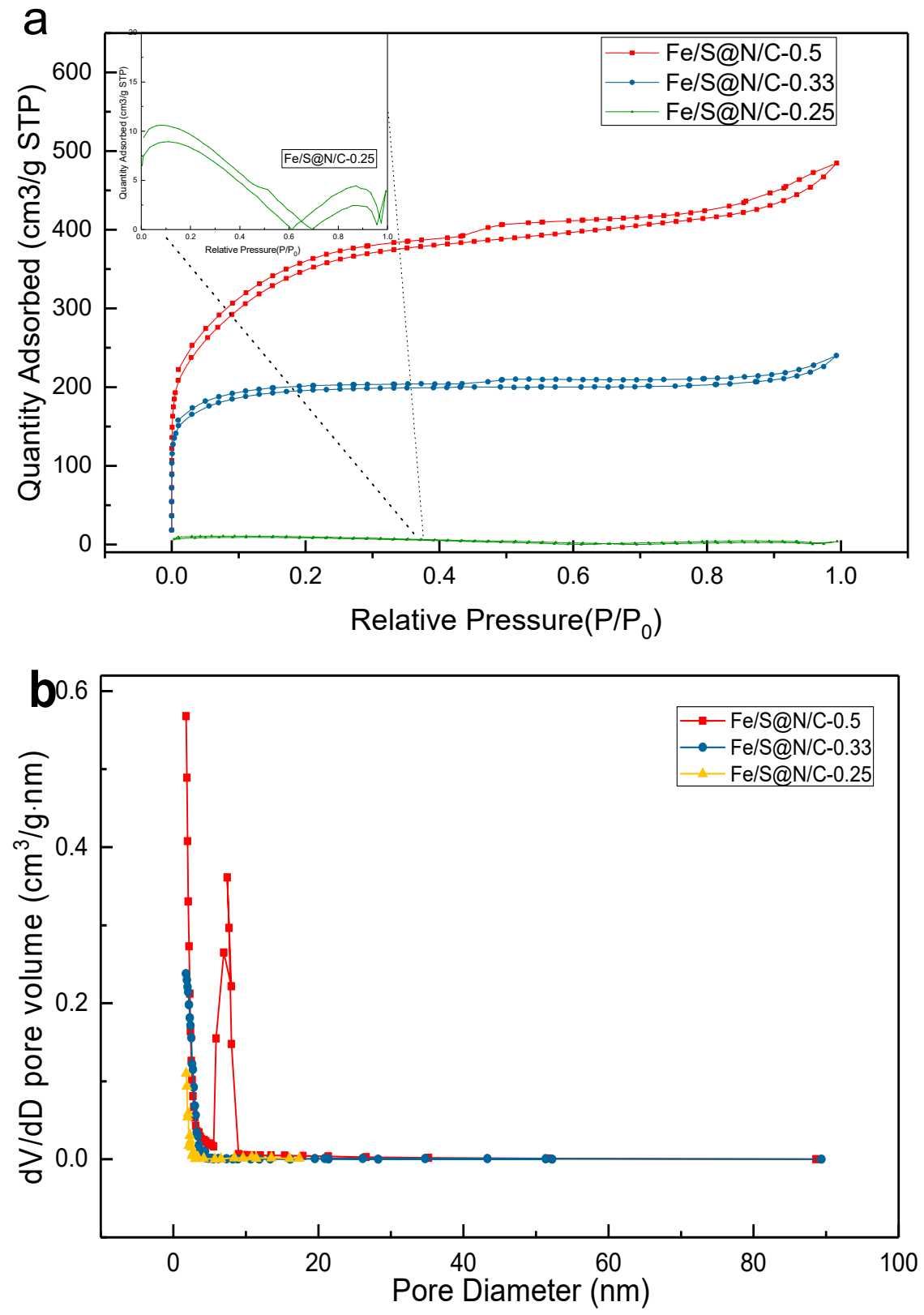

Figure 10. (a) $\mathrm{N}_{2}$ adsorption/desorption isotherms of Fe/S@N/C-x. (b) Pore size distribution data obtained by the Barrett-Joyner-Halenda (BJH) method of Fe/S@N/C-x.

The content of iron has a remarkable effect on the pore structure. When the $\mathrm{x}$ value changes, the stability of the material structure is different, probably originating from the instability of the different building units derived from the different coordination numbers and geometries. Hence, based 
on this, the pristine MOF with a different stability may generate a structural rearrangement process during carbonization, where the leaving of $\mathrm{O}$ and $\mathrm{H}$ makes the original framework shrink and the gaseous products create the formation of gas tunnels. Another reason could be that the $\mathrm{Fe} / \mathrm{S} @ \mathrm{~N} / \mathrm{C}-\mathrm{x}$ $(x=0.5)$ sample contains the highest iron content, and the corresponding unstable Fe species are due to the higher amounts, thus, resulting in the formation of more mesopores. In general, the pore structure of the catalyst plays an important role in the ORR for MFCs as mesoscale pores benefit the diffusion of larger molecules with low resistance, while the microscale pores can provide effective catalytic sites of small molecules [63]. Thus, compared with the other two Fe/S@N/C-x $(0.33,0.25)$ catalysts, the richness of the pores and the larger specific surface in the Fe/S@N/C-0.5 material contribute to the enhanced ORR activity of the MFC [64].

\section{Conclusions}

We announce a facile strategy to synthesize the Fe/S@N/C-0.5 composite derived from ZIF-8 with $\mathrm{FeS}$ as the main phase. The Fe/S@N/C-0.5 catalyst shows pronounced ORR activity and high reduction kinetics, in which the ORR is predominantly a four-electron pathway with longer-term durability and excellent methanol tolerance. In alkaline media, the Fe/S@N/C-0.5 catalyst showed a half-wave potential $\left(\mathrm{E}_{1 / 2}\right)$ of $0.87 \mathrm{~V}$ and a stronger diffusion-limiting current density $\left(J_{L}\right)$ of $6.16 \mathrm{~mA} \cdot \mathrm{cm}^{-1}$. In neutral PBS media, the Fe/S@N/C-0.5 catalyst showed a remarkable reduction potential at $-0.03 \mathrm{~V}$ (vs. SCE). When being employed as a cathode catalyst in an single-chamber microbial fuel cell (MFC) of the air cathode, the prepared Fe/S@N/C-0.5 catalyst could outperform the commercial 20\% Pt-C catalyst as far as the most important performance indicators of MFC are concerned. The Fe/S@N/C-0.5-MFC had a high OCV of $0.71 \mathrm{~V}$ and large maximum power density of $1196 \mathrm{~mW} / \mathrm{m}^{2}$, both of which are beyond $\mathrm{Pt} / \mathrm{C}-\mathrm{MFC}$ under the same conditions. Furthermore, it had a more stable and higher output voltage during its operation compared with $\mathrm{Pt} / \mathrm{C}-\mathrm{MFC}$. These results demonstrate that the $\mathrm{Fe}, \mathrm{N}$, and $\mathrm{S}$ co-doped Fe/S@N/C-0.5 is a robust catalyst for the oxygen reduction reaction in microbial fuel cells.

Author Contributions: Conceptualization, X.L.; Data curation, W.H., H.R. and Q.Z.; Formal analysis, W.H., H.R. and Q.Z.; Funding acquisition, X.L.; Investigation, X.L.; Methodology, W.H., H.R. and Q.Z.; Software, W.H., H.R. and Q.Z.; Writing-original draft, X.L. and W.H.; Writing—review \& editing, X.L.

Funding: This research was funded by Open Project Program of State Key Laboratory of Petroleum Pollution Control, CNPC Research Institute of Safety and Environmental Technology (PPC2017002), and The APC was funded by Open Project Program of State Key Laboratory of Petroleum Pollution Control, CNPC Research Institute of Safety and Environmental Technology.

Conflicts of Interest: The authors declare no conflict of interest.

\section{References}

1. Guo, S.J.; Zhang, S.; Sun, S.S. Tuning Nanoparticle Catalysis for the Oxygen Reduction Reaction. Angew. Chem. Int. Ed. 2013, 52, 8526-8544. [CrossRef] [PubMed]

2. Jaouen, F.; Proietti, E.; Lefèvre, M.; Chenitz, R.; Dodelet, J.-P.; Wu, G.; Chung, H.T.; Johnstonb, C.M.; Zelenay, P. Recent advances in non-precious metal catalysis for oxygen-reduction reaction in polymer electrolyte fuel cells. Energy Environ. Sci. 2011, 4, 114-130. [CrossRef]

3. Hara, M.; Kitano, M.; Hosono, H. Ru-loaded C12A7: E' electride as a catalyst for ammonia synthesis. ACS Catal. 2017, 7, 2313-2324. [CrossRef]

4. Kitano, M.; Kanbara, S.; Inoue, Y.; Kuganathan, N.; Sushko, P.V.; Yokoyama, T.; Hara, M.; Hosono, H. Electride support boosts nitrogen dissociation over ruthenium catalyst and shifts the bottleneck in ammoia synthesis. Nat. Commun. 2015, 6, 6731. [CrossRef] [PubMed]

5. Zhu, C.Z.; Dong, S.J. Recent progress in graphene-based nanomaterials as advanced electrocatalysts towards oxygen reduction reaction. Nanoscale 2013, 5, 1753-1767. [CrossRef]

6. Zhang, C.; Mahmood, N.; Yin, H.; Liu, F.; Hou, Y. Synthesis of Phosphorus-Doped Graphene and its Multifunctional Applications for Oxygen Reduction Reaction and Lithium Ion Batteries. Adv. Mater. 2013, 25, 4932-4937. [CrossRef] 
7. Liang, J.; Zheng, Y.; Chen, J.; Liu, J.; Hulicova-Jurcakova, D.; Jaroniec, M.; Qiao, S.Z. Facile Oxygen Reduction on a Three-Dimensionally Ordered Macroporous Graphitic $\mathrm{C}_{3} \mathrm{~N}_{4}$ /Carbon Composite Electrocatalyst. Angew. Chem. Int. Ed. 2012, 51, 3892-3896. [CrossRef]

8. Lefevre, M.; Proietti, E.; Jaouen, F.; Dodelet, J.-P. Iron-Based Catalysts with Improved Oxygen Reduction Activity in Polymer Electrolyte Fuel Cells. Science 2009, 324, 71-74. [CrossRef]

9. Yun, J.; Smith, V.H.; Pate, R.C. Managing nutrients and system operations for biofuel production from freshwater macroalgae. Algal Res. 2015, 11, 13-21. [CrossRef]

10. Quek, S.B.; Cheng, L.; Cord-Ruwisch, R. Microbial fuel cell biosensor for rapid assessment of assimilable organic carbon under marine conditions. Water Res. 2015, 77, 64-71. [CrossRef]

11. Liew, K.B.; Daud, W.R.W.; Ghasemi, M. Non-Pt catalyst as oxygen reduction reaction in microbial fuel cells: A review. Int. J. Hydrog. Energy 2014, 39, 4870-4883.

12. Aspear, S.; Kawai, H. Density functional theory-based analysis on $\mathrm{O}_{2}$ molecular interaction with the tri-s-triazine-based graphitic carbon nitride. Surf. Sci. 2012, 606, 892-901. [CrossRef]

13. Zhu, C.Z.; Fu, S.F.; Song, J.H.; Shi, Q.R.; Su, D.; Mark, H.; Engelhard, X.L. Self-Assembled Fe-N-Doped Carbon Nanotube Aerogels with Single-Atom Catalyst Feature as High-Efficiency Oxygen Reduction Electrocatalysts. Small 2017, 13, 1603407. [CrossRef] [PubMed]

14. Yang, Z.; Zhao, Z.; Liang, K.; Zhou, X.; Shen, C.; Liu, Y.; Wang, X.; Xu, A. Synthesis of nanoporous structured iron carbide/Fe-N-carbon composites for efficient oxygen reduction reaction in $\mathrm{Zn}$-air batteries. J. Mater. Chem. A 2016, 4, 19037-19044. [CrossRef]

15. Deng, D.H.; Yu, L.; Chen, X.Q.; Wang, G.X.; Jin, L.; Pan, X.L.; Deng, J.; Sun, G.Q.; Bao, X.H. Iron Encapsulated within Pod-like Carbon Nanotubes for Oxygen Reduction Reaction. Angew. Chem. 2013, 52, 371-375. [CrossRef] [PubMed]

16. Sun, Z.; An, L.; Jiang, N.; Li, B.; Hua, S.; Fu, Y.; Liu, J.; Hao, W.; Xia, D. A highly active and durable iron/cobalt alloy catalyst encapsulated in N-doped graphitic carbon nano. J. Mater. Chem. A 2018, 6, 5962-5970.

17. Bracamonte, V.; Melchionna, M.; Stopin, A.; Giulani, A. Carboxylated, Fe-Filled Multiwalled Carbon Nanotubes as Versatile Catalysts for $\mathrm{O}_{2-}$ Reduction and $\mathrm{H}_{2-}$ Evolution Reactions at Physiological $\mathrm{pH}$. Chem. Eur. J. 2015, 21, 12769-12777. [CrossRef]

18. Li, J.Z.; Chen, M.J.; David, A.; Wang, M.Y. Atomically dispersed manganese catalysts for oxygen reduction in proton-exchange membrane fuel cells. Nat. Catal. 2018, 1, 935-945. [CrossRef]

19. Anna, L.; Manuela, B.; Claudio, T.; Lucia, N. Selective Electrocatalytic $\mathrm{H}_{2} \mathrm{O}_{2}$ Generation by Cobalt@N-Doped Graphitic Carbon Core-Shell Nanohybrids. ChemSusChem 2019, 12, 1664-1672.

20. Wang, Q.; Zhou, Z.Y.; Lai, Y.J.; You, Y.; Liu, J.G.; Wu, X.L.; Terefe, E.; Chen, C.; Song, L.; Rauf, M.; et al. Phenylenediamine-Based FeNx/C Catalyst with High Activity for Oxygen Reduction in Acid Medium and Its Active-Site Probing. Am. Chem. Soc. 2014, 136, 10882-10885. [CrossRef]

21. Chung, H.T.; Cullen, D.A.; Higgins, D. Direct atomic-level insight into the active sites of a high-performance PGM-free ORR catalyst. Science 2017, 357, 479-484. [CrossRef] [PubMed]

22. Perez-Alonso, F.J.; Dominguez, C.; Al-Thabaiti, S.A. Evidences of the presence of different types of active sites for the oxygen reduction reaction with Fe/N/C based catalysts. J. Power Sources 2016, 327, $204-211$. [CrossRef]

23. Ingale, P.; Sakthivel, M.; Drillet, J.F. Test of Diethylmethylammonium Trifluoromethanesulfonate Ionic Liquid as Electrolyte in Electrically Rechargeable Zn/Air Battery. J. Electrochem. Soc. 2017, 164, H5224-H5229. [CrossRef]

24. Zhang, J.; Xu, D.; Wang, C.; Guo, J.; Yan, F. Rational Design of $\mathrm{Fe}_{1-\mathrm{x}} \mathrm{S} / \mathrm{Fe}_{3} \mathrm{O}_{4} /$ Nitrogen and Sulfur Doped Porous Carbon with Enhanced Oxygen Reduction Reaction Catalytic Activity. Adv. Mater. Interfaces 2018. [CrossRef]

25. Liu, B.H.; Li, Z.P. Current status and progress of direct borohydride fuel cell technology development. J. Power Sources 2009, 187, 291-297. [CrossRef]

26. Gorlin, Y.; Lassalle-Kaiser, B.; Benck, J.D.; Gul, S.; Webb, S.M.; Yachandra, V.K.; Yano, J.; Jaramillo, T.F. In-Situ X-Ray Absorption Spectroscopy Investigation of a Bifunctional Manganese Oxide Catalyst with High Activity for Electrochemical Water Oxidation and Oxygen Reduction. J. Am. Chem. Soc. 2013, 135, 8525-8534. [CrossRef] [PubMed]

27. Pampel, J.; Fellinger, T.-P. Opening of Bottleneck Pores for the Improvement of Nitrogen Doped Carbon Electrocatalysts. Adv. Energy Mater. 2016, 6, 1502389. [CrossRef] 
28. Schaber, P.; Colson, J.; Higgins, S.; Thieln, D.; Anspach, B.; Brauer, J. Thermal de-composition (pyrolysis) of urea in an open reaction vessel. Thermochim. Acta 2004, 424, 131-142. [CrossRef]

29. Olszowska, K.; Pang, J.; Wrobel, P.S.; Zhao, L.; Ta, H.Q.; Liu, Z.; Trzebicka, B.; Bachmatiuk, A.; Rummeli, M.H. Three-dimensional nanostructured graphene: Synthesis and energy, environmental and biomedical applications. Synth. Met. 2017, 234, 53-85. [CrossRef]

30. Fei, H.L.; Yang, Y.; Fan, X.J.; Wang, G.; Ruan, G.D.; Tour, J.M. Tungsten-Based Porous Thin-Films for Electrocatalytic Hydrogen Generation-Electronic Supplementary Information. J. Mater. Chem. A 2015, 3, 5798-5804. [CrossRef]

31. Stoerzinger, K.A.; Hong, W.T.; Azimi, G.; Giordano, L.; Lee, Y.-L.; Crumlin, E.J.; Biegalski, M.D.; Bluhm, H.; Varanasi, K.K.; Shao-Horn, Y. Reactivity of Perovskites with Water: Role of Hydroxylation in Wetting and Implications for Oxygen Electrocatalysis. J. Phys. Chem. C 2015, 119, 18504-18512. [CrossRef]

32. Liu, S.; Yang, Z.; Li, M.; Liu, L.; Wang, Y.; Lv, W.; Qin, Z.; Zhao, X.; Zhu, P.; Wang, G. FeS-decorated hierarchical porous $\mathrm{N}, \mathrm{S}$-dual-doped carbon derived from silica-ionogel as an efficient catalyst for oxygen reduction reaction in alkaline media. Electrhochim. Acta 2018, 265, 221-231. [CrossRef]

33. Ma, X.X.; $\mathrm{Su}, \mathrm{Y}$; $\mathrm{He}, \mathrm{X} . \mathrm{Fe}_{9} \mathrm{~S}_{10}$-decorated N, $\mathrm{S}$ co-doped graphene as a new and efficient electrocatalyst for oxygen reduction and oxygen evolution reactions. Catal. Sci. Technol. 2017, 7, 1181-1192. [CrossRef]

34. Lalande, G.; Côté, R.; Tamizhmani, G.; Guay, D.; Dodelet, J.P.; Dignard-Bailey, L.; Weng, L.T.; Bertrand, P. Physical, chemical and electrochemical characterization of heat-treated tetracarboxylic cobalt phthalocyanine adsorbed on carbon black as electrocatalyst for oxygen reduction in polymer electrolyte fuel cells. Electrochim. Acta 1995, 40, 2635-2646. [CrossRef]

35. Morris, J.M.; Jin, S.; Wang, J.; Zhu, C.; Urynowicz, M.A. Lead dioxide as an alternative catalyst to platinum in microbial fuel cells. Electrochem. Commun. 2007, 9, 1730-1734. [CrossRef]

36. Valipour, A.; Ayyaru, S.; Ahn, Y. Application of graphene-based nanomaterials as novel cathode catalysts for improving power generation in single chamber microbial fuel cells. J. Power Sources 2016, 327, 548-556. [CrossRef]

37. Santoro, C.; Serov, A.; Narvaez Villarrubia, C.W.; Stariha, S.; Babanova, S.; Schuler, A.J.; Artyushk, K.; Atanassov, P. Double-chamber microbial fuel cell with a non-platinum-group metal Fe-N-C cathode catalyst. ChemSusChem 2015, 8, 828-834. [CrossRef]

38. Feng, L.; Yan, Y.; Chen, Y.; Wang, L. Nitrogen-Doped Carbon Nanotubes as Efficient and Durable Metal-Free Cathodic Catalysts for Oxygen Reduction in Microbial Fuel Cells. Energy Environ. Sci. 2011, 4, 1892-1899. [CrossRef]

39. Santoro, C.; Li, B.; Cristiani, P.; Squadrito, G. Power generation of microbial fuel cells (MFCs) with low cathodic platinum loading. Int. J. Hydrog. Energy 2013, 38, 692-700. [CrossRef]

40. Kannan, M.V.; Kumar, G.G. Current status, key challenges and its solutions in the design and development of graphene based ORR catalysts for the microbial fuel cell applications. Biosens. Bioelectron. 2016, 77, 1208-1220. [CrossRef]

41. Rabaey, K.; Verstraete, W. Microbial fuel cells: Novel biotechnology for energy generation. Trends Biotechnol. 2005, 23, 291-298. [CrossRef] [PubMed]

42. Sun, L.; Tian, C.; Fu, Y.; Yang, Y.; Yin, J.; Wang, L.; Fu, H. Nitrogen-doped porous graphitic carbon as an excellent electrode material for advanced supercapacitors. Chem. A Eur. J. 2014, 20, 564-574. [CrossRef] [PubMed]

43. Bi, L.; Ci, S.; Cai, P.; Li, H.; Wen, Z. One-step pyrolysis route to three dimensional nitrogen-doped porous carbon as anode materials for microbial fuel cells. Appl. Surf. Sci. 2018, 427, 10-16. [CrossRef]

44. Cheng, H.; Scott, K. Investigation of non-platinum cathode catalysts for direct borohydride fuel cells. J. Electroanal. Chem. 2006, 596, 117-123. [CrossRef]

45. Cheng, S.; Liu, H.; Logan, B.E. Increased performance of single-chamber microbial fuel cells using an improved cathode structure. Electrochem. Commun. 2006, 8, 489-494. [CrossRef]

46. Santoro, C.; Serov, A.; Villarrubia, C.W.N.; Stariha, S.; Babanova, S.; Artyushkova, K.; Schuler, A.J.; Atanassov, P. High catalytic activity and pollutantsresistivity using Fe-AAPyr cathode catalyst for microbial fuel cell application. Sci. Rep. 2015, 5, 16596. [CrossRef] [PubMed]

47. Jiang, T.; Wang, Y.; Wang, K.; Liang, Y.; Wu, D.; Tsiakaras, P.; Song, S. A novel sulfur-nitrogen dual doped ordered mesoporous carbon electrocatalyst for efficient oxygen reduction reaction. Appl. Catal. B Environ. 2016, 189, 11. [CrossRef] 
48. Bayram, E.; Yilmaz, G.; Mukerjee, S. A solution-based procedure for synthesis of nitrogen doped graphene as an efficient electrocatalyst for oxygen reduction reactions in acidic and alkaline electrolytes. Appl. Catal. B Environ. 2016, 192, 26-34. [CrossRef]

49. Guerrini, E.; Grattieri, M.; Faggianelli, A.; Cristiani, P.; Trasatti, S. PTFE effect on the electrocatalysis of the oxygen reduction reaction in membraneless microbial fuel cells. Bioelectrochemistry 2015, 106, 240-247. [CrossRef] [PubMed]

50. Watson, V.J.; Delgado, C.N.; Logan, B.E. Influence of Chemical and Physical Properties of Activated Carbon Powders on Oxygen Reduction and Microbial Fuel Cell Performance. Environ. Sci. Technol. 2013, 47, 6704-6710. [CrossRef] [PubMed]

51. Freguia, S.; The, E.H.; Boon, N.; Leung, K.M.; Keller, J.; Rabaey, K. Microbial fuel cells operating on mixed fatty acids. Bioresour. Technol. 2010, 101, 1233-1238. [CrossRef] [PubMed]

52. Subbaraman, R.; Tripkovic, D.; Chancg, K.C.; Strmcnik, D.; Paulikas, A.P.; Hirunsit, P.; Chan, M.; Greeley, J.; Stamenkovic, V.; Markovic, N.M. Trends in activity for the water electrolyser reactions on $3 \mathrm{~d} \mathrm{M}(\mathrm{Ni}, \mathrm{Co}, \mathrm{Fe}, \mathrm{Mn})$ hydr(oxy)oxide catalyst. Nat. Mater. 2012, 11, 550-557. [CrossRef] [PubMed]

53. Malik, D.J.; Trochimczuk, A.W.; Jyo, A.; Tylus, W. Synthesis and Characterization of nanostructured carbons with controlled porosity prepared from sulfonated divinylbiphenyl copolymers. Carbon 2008, 46, 310-319. [CrossRef]

54. Li, Q.; Chen, W.; Xiao, H.; Gong, Y.; Li, Z.; Zheng, L.; Yan, W.; Cheong, W.; Shen, R.; Fu, N.; et al. Fe Isolated Single Atoms on S, N Codoped Carbon by Copolymer Pyrolysis Strategy for Highly Efficient Oxygen Reduction Reaction. Adv. Master. 2018, 30, 1800588. [CrossRef] [PubMed]

55. Men, B.; Sun, Y.; Liu, J.; Tang, Y.; Chen, Y.; Wan, P.; Pan, J. Synergistically Enhanced Electrocatalytic Activity of Sandwich-like N-Doped Graphene/Carbon Nanosheets Decorated by Fe and S for Oxygen Reduction Reaction. ACS Appl. Master. Interfaces 2016, 30, 19533-19541. [CrossRef] [PubMed]

56. Li, Q.; Wu, G.; Cullen, D.A.; More, K.L.; Mack, N.H.; Chung, H.T.; Zelenay, P. Phosphate-Tolerant Oxygen Reduction Catalysts. ACS Catal. 2014, 4, 3193-3200. [CrossRef]

57. Zitolo, A.; Goellner, V.; Armel, V.; Sougrati, M.-T.; Mineva, T.; Stievano, L.; Fonda, E.; Jaouen, F. Identification of catalytic sites for oxygen reduction in iron- and nitrogen-doped graphene materials. Nat. Mater. 2015, 14, 937-942. [CrossRef] [PubMed]

58. Nguyen, M.-T.; Mecheri, B.; Iannaci, A.; D’Epifanio, A.; Licoccia, S. Iron/polyindole-based electrocatalysts to enhance oxygen reduction in microbial fuel cells. Electrochim. Acta 2016, 190, 388-395. [CrossRef]

59. Haolin, T.; Yan, Z.; Yin, Z.; Rui, W.; Shichang, C.; Cong, L.; Haopeng, C. Iron-embedded nitrogen doped carbon frameworks as robust catalyst for oxygen reduction reaction in microbial fuel cells. J. Power Sources 2014, 202, 550-556.

60. Bruce, P.G.; Freunberger, S.A.; Hardwick, L.J.; Tarascon, J.M. Li-O 2 and Li-S batteries with high energy storage. Nat. Mater. 2012, 11, 19-29. [CrossRef]

61. Ferrandon, M.; Kropf, A.J.; Myers, D.J. Multitechnique Characterization of a Polyaniline-Iron-Carbon Oxygen Reduction Catalyst. J. Phys. Chem. C 2012, 116, 16001-16013. [CrossRef]

62. Armel, V.; Hindocha, S.; Salles, F. Structural Descriptors of Zeolitic-Imidazolate Frameworks Are Keys to the Activity of Fe-N-C Catalysts. J. Am. Chem. Soc. 2017, 139, 453-464. [CrossRef] [PubMed]

63. Jiang, W.J.; Gu, L.; Li, L. Understanding the High Activity of Fe-N-C Electrocatalysts in Oxygen Reduction: Fe/Fe3C Nanoparticles Boost the Activity of Fe-Nx. J. Am. Chem. Soc. 2016, 138, 3570-3578. [CrossRef] [PubMed]

64. Kim, S.-W.; Seo, D.-H.; Ma, X.; Ceder, G.; Kang, K. Electrode Materials for rechargeable sodium-ion batteries: Potential alternatives to current lithium-ion batteries. Adv. Energy Mater. 2012, 2, 710-721. [CrossRef]

C 2019 by the authors. Licensee MDPI, Basel, Switzerland. This article is an open access article distributed under the terms and conditions of the Creative Commons Attribution (CC BY) license (http://creativecommons.org/licenses/by/4.0/). 